\title{
Evaluation of macroseismic intensity, strong ground motion pattern and fault model of the 19 July 2019 Mw5.1 earthquake west of Athens
}

\author{
V. Kouskouna $(\mathbb{D} \cdot$ A. Ganas • M. Kleanthi • I. Kassaras • N. Sakellariou • G. Sakkas • S. \\ Valkaniotis • E. Manousou • G. Bozionelos • V. Tsironi • I. Karamitros • N. Tavoularis • \\ Ch. Papaioannou $\cdot$ R. Bossu
}

Received: 13 May 2020 / Accepted: 2 February 2021 / Published online: 13 April 2021

(C) The Author(s) 2021

\begin{abstract}
This paper presents a joint analysis of instrumental and macroseismic data regarding the $19 \mathrm{Ju}-$ ly 2019, Greece $\mathrm{M}_{\mathrm{w}} 5.1$ earthquake occurred west of Athens. This earthquake ruptured a blind, southdipping normal fault, $23 \mathrm{~km}$ WNW of the center of Athens, while its relocated epicentre lies in close vicinity to the one of the $1999 \mathrm{M}_{\mathrm{w}} 6.0$ earthquake. The maximum macroseismic intensity of the 2019 mainshock reached IEMS98 $=7.5$. Scarce damage and intensities up to 5-6 were reported in the epicentral area. Higher intensities were observed at larger distances, $12-$ $15 \mathrm{~km}$ east and ESE of the epicentre, alongside the banks of Kifissos River, likely related to ground motion
\end{abstract}

V. Kouskouna $(\bowtie) \cdot$ I. Kassaras $\cdot$ N. Sakellariou •

G. Sakkas · E. Manousou • G. Bozionelos

Seismological Laboratory, Department of Geology and

Geoenvironment, National and Kapodistrian University of Athens,

Panepistimiopolis, 15784 Zografou, Athens, Greece

e-mail: vkouskouna@geol.uoa.gr

A. Ganas · G. Bozionelos · V. Tsironi · I. Karamitros Institute of Geodynamics, National Observatory of Athens, Athens, Greece

M. Kleanthi

Directorate General for Natural Disasters Rehabilitation, Ministry of Infrastructure and Transport, Athens, Greece

G. Sakkas

Center for Security Studies, Athens, Greece amplification due to soft alluvial formations. Similar selectivity of increased ground motions to the east of the epicentre with respect to other azimuths, also observed during the 1981 and 1999 earthquakes, supports eastward rupture directivity of the 2019 mainshock, an effect that is possibly common for the region's fault system. Damping of seismic effects was observed east of Aegaleo Mountain, a structure suggested to impose a stopping phase in the time histories of the 1999 and 2019 earthquakes (Fig. A1).

Keywords Athens - Attica Earthquake $\cdot$ Macroseismic intensity $\cdot$ Strong motion data $\cdot$ Fault model

S. Valkaniotis

Trikala, Greece

N. Tavoularis

Administration of Attica, Athens, Greece

C. Papaioannou

ITSAK-OASP, Thessaloniki, Greece

R. Bossu

European-Mediterranean Seismological Centre (EMSC),

Bruyères-le-Châtel, France

R. Bossu

CEA, DAM, DIF, F-91297 Arpajon, France 


\section{Introduction}

On 19 July 2019, 11:13 GMT (14:13 local time), a strong, damaging earthquake with magnitude $M_{w} 5.1$ (Fig. 1) and $8 \mathrm{~km}$ depth (NKUA solution; Kapetanidis et al. 2020) struck the broader area of Athens, causing damage to its western suburbs. This moderate event signalled a general alarm in the whole metropolitan area with people rushing out of buildings, resulting in interruption of mobile communication for at least $2 \mathrm{~h}$ and heavy traffic jams. The epicentre, associated with a normal fault, was located $5 \mathrm{~km}$ north of Magoula (Fig. A1), in the prefecture of Attica, a broader area delimited by the coordinates $37.8-38.2^{\circ} \mathrm{N}, 23.4-24.1^{\circ} \mathrm{E}$.

The mountainous area of Parnitha (Fig. A1) is a relatively low strain-rate area of Central Greece $(\sim 30$ 50 nanostrain/year). Strain-rates are dilatational and increase from east towards west, while the extension direction is in general NNE-SSW (Chousianitis et al. 2015). The northern part of Parnitha Mt. is bounded by a series of north-dipping active fault segments, while the southern part by south-dipping active faults, respectively. The slip rates of active faults are less than $1 \mathrm{~mm} /$ year (Ganas et al. 2005), and average earthquake recurrence intervals are expected to be in the order of a few thousands of years.

On 7 September 1999, the area east of the 2019 earthquake was activated with an $\mathrm{M}_{\mathrm{w}} 6.0$ event (Papadimitriou et al. 2002), which resulted in 143 fatalities and considerable damage estimated at $€ 3$ billion to a large number of municipalities north, west and south of Athens, as well as in the capital city itself. Damage was particularly heavy in the western and north-western suburbs of Athens, severely affecting a population of approximately one million (Kouskouna and Malakatas 2000). This unexpected earthquake was the main cause

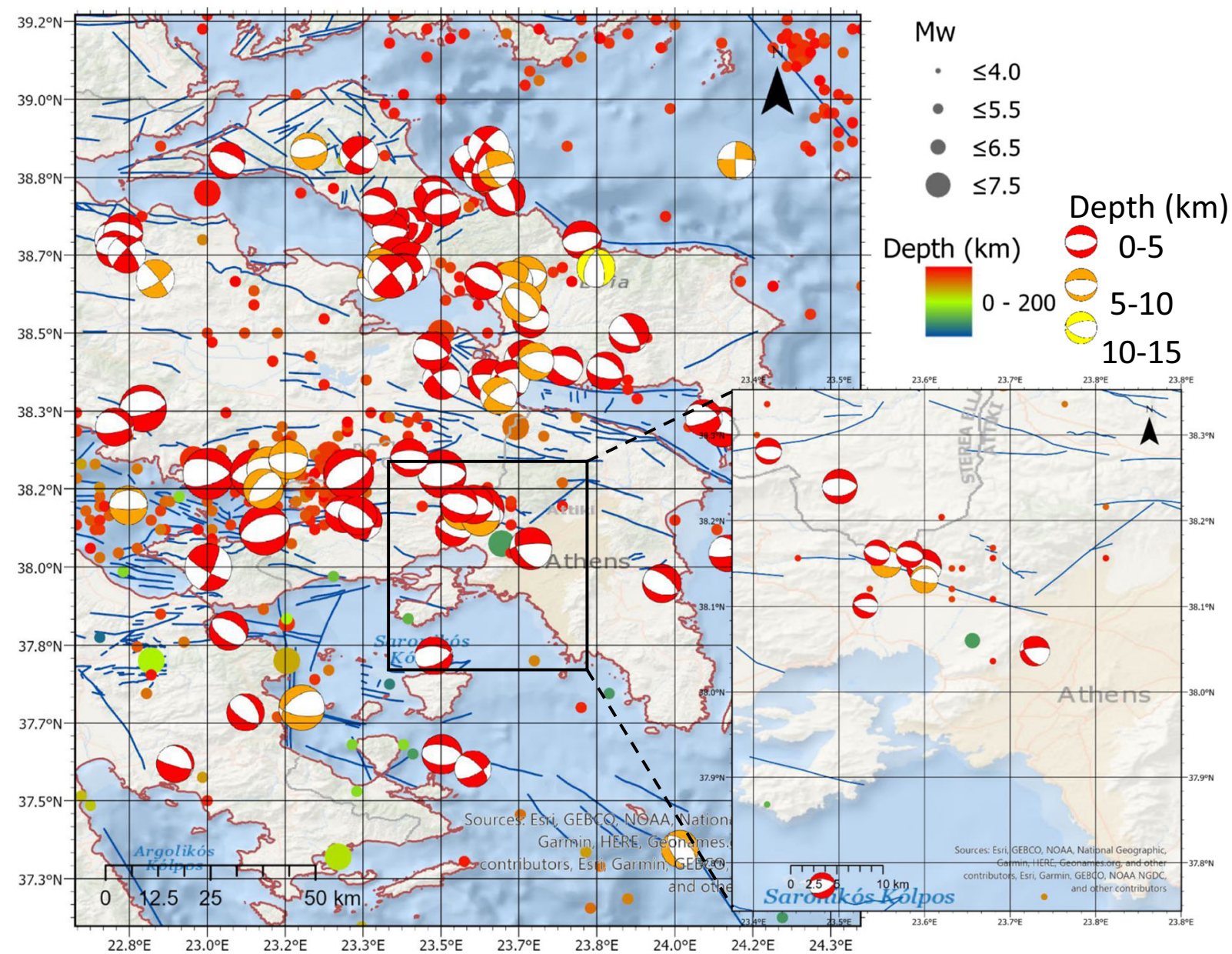

Fig. 1 Map of the broader epicentral region showing focal mechanisms and epicentres of earthquakes with $\mathrm{M} \geq 4.0$ after 1964 (solid circles). Thin blue lines are active faults. Inset box indicates the study area (from Kassaras et al. 2020) 


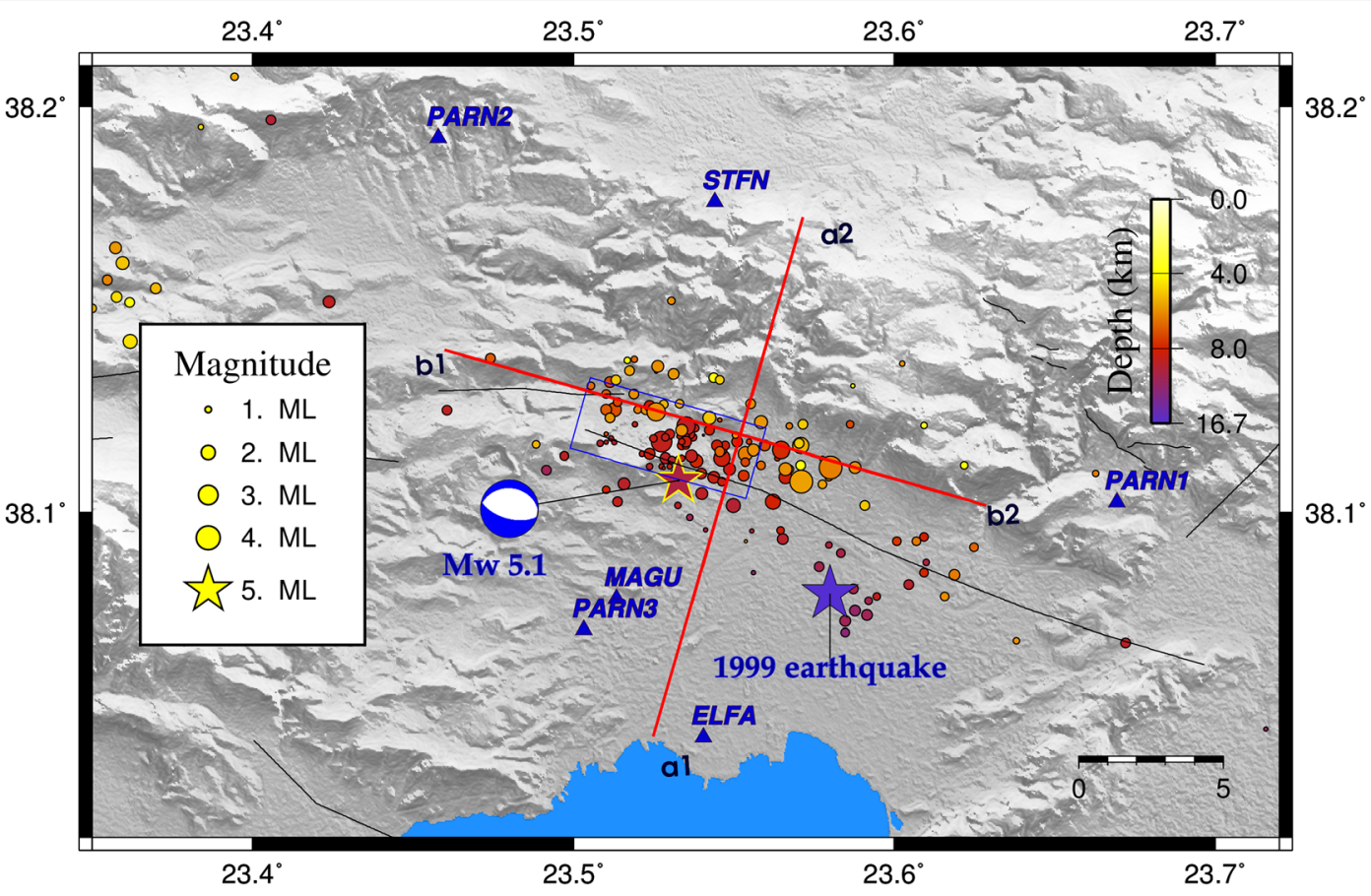

Fig. 2 Map showing the relocated Mw5.1 mainshock of 19/07/ 2019 (red star) and the aftershock sequence (solid circles coloured according to depth,). Blue triangles indicate locations of temporary seismic stations which were complementary used in this study.

for the update of the national seismic code to adopt 3 PGA zones instead of the previous 4 for the entire country. Athens metropolitan area belongs to zones I
Beachball displays the focal mechanism of the earthquake (NOA solution). The M6.0 earthquake of 7/9/1999 is plotted with a purple star. Cross-sections a-a1-a2 and b1-b2 are shown on Fig. 3

(eastern part) and II (western part), with design acceleration values of $0.16 \mathrm{~g}$ and $0.24 \mathrm{~g}$ for a $10 \%$ exceedance in 50 years (EAK 2000, amendment of 2003).

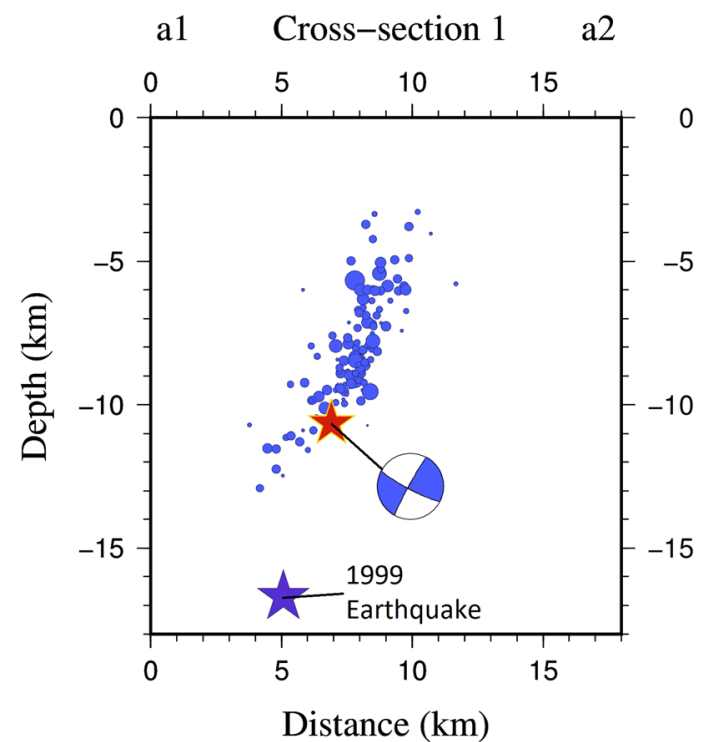

Fig. 3 Cross sections of hypocentral locations along the profiles a and $\mathrm{b}$ in Fig. 2. A south-dipping fault plane is inferred from the geometry of the aftershock distribution (beachball indicates b1 Cross-section 2 b2

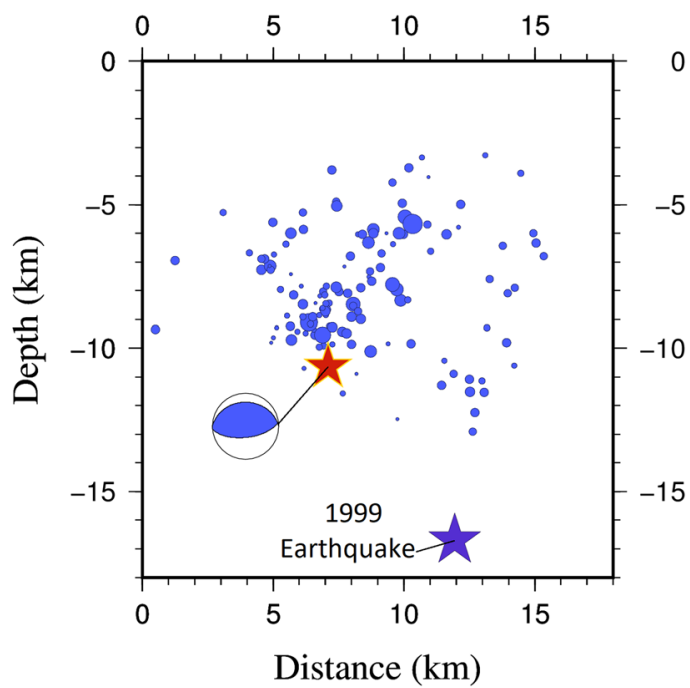

projection of focal mechanism solution of the mainshock). The M6.0 earthquake of 7/9/1999 is projected with a purple star 
Despite the magnitude of the 2019 earthquake, the macroseismic report, published by our team, on the extent and magnitude of damage (Kouskouna et al. 2019) showed that post-seismic repairs to damaged buildings in areas already affected by the 1999 earthquake, likely contributed to the damage extent during the 2019 earthquake. In that macroseismic report, we refer to the 2019 earthquake as the Magoula earthquake, keeping in mind that Athens is the largest city affected near the epicentre.

The first part of this work deals with the improvement of hypocentral locations via nonlinear relocation. Following, we present the collection and processing of macroseismic data. Next, we discuss the analysis of strong motion recordings of the mainshock provided by the NOA (bbnet.gein.noa.gr) and ITSAK (www. itsak.gr) networks (ITSAK 2019). Lastly, we combine macroseismic, instrumental data and fault model, in order to estimate ground motion parameters of engineering interest, that affect the macroseismic field towards a better understanding of seismic risk in the broader metropolitan area of Athens.

\section{Data and methods}

\subsection{Relocation of mainshock and aftershock sequence}

One question arising regards the source of the 2019 event and whether it (a) would comprise the western segment of the Parnitha (Fili) normal fault that produced the $\mathrm{M}_{\mathrm{w}} 6.0$ earthquake on 7 September 1999 (Fig. 1, A1 and 2; Pavlides et al. 1999, Papazachos et al. 2001, Lekkas 2001, Ganas et al. 2001, 2004, Papadimitriou et al. 2002, Atzori et al. 2008) or (b) if it is caused by another active fault sub-parallel to the latter.

For the period 19 July 2019-6 September 2019, 154 aftershocks were relocated using phase data from HUSN (Hellenic Unified Seismic Network) and a temporary local network of six stations installed by NOA and NKUA (Figs. 2 and 3). The nonlinear location software NonLinLoc (NLL; Lomax et al. 2000) was applied. NLL follows the probabilistic formulation of nonlinear inverse problems (Tarantola and Valette 1982), yielding a probabilistic solution, much more robust in the presence of outliers, thus avoiding location uncertainties, typically derived from linearised earthquake location algorithms (Husen et al. 2003).
Several velocity models, available from previous studies in the region, were tested in order to obtain the most accurate hypocentral solutions (Tables A1, A2). The selection was done after evaluation of the spatial uncertainties for each event and additionally the travel time residuals for each station (Table 1). The best results were obtained using the velocity model of Zahradnik (2001) and a $V_{P} / V_{S}=1.78$ ratio (Table A1). Overall, the hypocentral solutions have low spatial errors, with an average horizontal (ERH) and vertical error (ERZ) of $1.3 \mathrm{~km}$ and $1.5 \mathrm{~km}$ respectively, and an average RMS $=0.15 \mathrm{~s}$ (Fig. A2, Table 2). The mainshock (July 19, 2019 11:13:15.95 UTC) was relocated at $38.1080^{\circ} \mathrm{N}-23.5327^{\circ} \mathrm{E}$ at a depth of $10.7 \mathrm{~km}( \pm 1.3 \mathrm{~km}$, Table 1, Fig. 2). The largest aftershock, occurred on the same day (19 July 2019, 12:11:54 UTC; $\mathrm{M}_{\mathrm{L}-\mathrm{NOA}}=4.3$ ) and was relocated at $38.1112^{\circ} \mathrm{N}-$ $23.5802^{\circ} \mathrm{E}$ at a depth of $6.28 \mathrm{~km}$. One hundred fifty-four aftershocks were finally relocated having (a) ERH less than $2 \mathrm{~km}$ and ERZ $<2.5 \mathrm{~km}$, (b) RMS $<0.7 \mathrm{~s}$ and (c) azimuthal GAP $<250^{\circ}$, (Fig. 2, A2).

A cross section drawn in NNE-SSW direction indicates that the mainshock occurred on a south-dipping normal fault (Fig. 3, section a1-a2). Most aftershocks occurred up-dip of the hypocenter between 5 and $10 \mathrm{~km}$ depths. In addition, most aftershocks occurred on the hanging-wall block either co-planar to the mainshock or within 1-2 km distance from the fault plane, indicating release of elastic strains close to the main rupture. The hypocenter of the mainshock is located at the deepest part of the rupture (see also section b1-b2). The dip-angle of the activated fault indicated by the alignment of aftershocks is $\sim 52^{\circ}$ (measured in section a1-a2), close to the value of the one of the nodal planes determined by moment tensor inversion of the mainshock by NOA, USGS, INGV and AUTH (50-61 ; Table 3). In general, the aftershocks are distributed in an overall WNW-ESE orientation and tend to form two clusters, one near the mainshock and a smaller one to the southeast (Figs. 2, 3b). This pattern agrees with the WNW-ESE orientation of the nodal planes of the moment tensor solutions (Table 3 ). Thus, we conclude that a WNW-ESE, south-dipping normal fault seems to be the causative fault.

2.2 Macroseismic data collection, vulnerability and intensity assignment

The transition from traditional questionnaire reports of the community persons-in-charge for online 
Table 1 Earthquake hypocentral parameters and associated errors determined for the mainshock. No number of stations used, $D M$ epicentral distance to the nearest station, GAP azimuthal gap, $R M S$ root mean square error of time residuals in sec, ERH horizontal error in $\mathrm{km}, E R Z$, vertical error in $\mathrm{km}$

\begin{tabular}{llllllllll}
\hline Time (UTC) & Lon & Lat & Depth & No & Dm & Gap & RMS & ERH & ERZ \\
\hline $190,719,111,315.95$ & 23.533 & 38.108 & 10.6 & 75 & 7 & 38 & 0.69 & 0.9 & 1.3 \\
\hline
\end{tabular}

questionnaires and citizen seismology is apparent within two decades between the two major earthquakes west of Athens (07 September $1999 \mathrm{M}_{\mathrm{w}} 6.0$ and 19 July 2019 $M_{\mathrm{w}}$ 5.1). For the 1999 event, 266 intensity values, assigned from traditional questionnaire reports, were published in the monthly bulletin of GI-NOA, while for the 2019 event, online intensity values and felt testimonies were reported to EMSC (https://www. seismicportal.eu/) and USGS, accompanied by questionnaire responses from in situ observations.

With regard to the 2019 earthquake, macroseismic information was collected through all possible practices (Fig. 4): in situ damage observations and distribution of questionnaires, damage inspections by engineers and online reports. The Macroseismic Field Investigation Team of the Department of Geology and Geoenvironment, National and Kapodistrian University of Athens (NKUA), distributed and collected the answers from 63 questionnaire felt reports based on EMS-98 and 48 damage photos from a number of suburbs, villages and towns near the epicentre, within a few hours after the earthquake and in the following week. The Field Investigation Team of the National Observatory of Athens (NOA) performed a field survey for the identification of slope failure effects at 8 sites. The Directorate General for Natural Disasters Rehabilitation, Ministry of Infrastructure and Transport (GDAEFK), conducted first- and second-order inspections to 4451 reported damaged buildings. Finally, 451 online testimonies and thumbnail were submitted to EMSC.

Table 2 Results of the aftershock statistics in tabular form. RMS is in $\mathrm{s}$, location errors are in $\mathrm{km}$, respectively

\begin{tabular}{llll}
\hline Metric & RMS & ERH & ERZ \\
\hline Average & 0.17 & 1.3 & 1.5 \\
Min & 0.04 & 0.6 & 0.5 \\
Max & 0.69 & 1.9 & 2.4 \\
Median & 0.16 & 1.3 & 1.4 \\
St. deviation & 0.07 & 0.34 & 0.5 \\
\hline
\end{tabular}

In downtown Athens, the walls of a couple of abandoned buildings partially collapsed, and failure of nonstructural elements was observed in a few others. In Piraeus port, part of an old abandoned conveyor collapsed. More damage was observed at the NW suburbs of Athens, situated $\mathrm{E}$ and SE of the epicentre (Fig. 5). In general, the earthquake caused structural damage to a few, high vulnerability specific buildings and slight-tomoderate damage, mainly to non-structural elements to ordinary buildings.

Evidence of minor rock falls along the road network to the SE of the epicentre was observed. No landslides were triggered, and no bedrock scarp or outcropping fault plane or surface breaks were observed, as expected due to the moderate magnitude of the mainshock (Fig. 4).

\subsection{Intensity data and analysis}

The variety of available macroseismic information from villages, towns, suburb municipalities, or urban municipal boroughs, requires an independent handling of each dataset, in order to resolve final intensity assignment. At a first glance, most information is reported from the prefecture of Attica, with the intensities greater than 5 confined within this region. Three data sources, i.e. EMSC, NKUA and GDAEFK were used and elaborated (Kouskouna et al. 2019).

\subsubsection{EMSC data}

While macroseismic intensities have been traditionally collected through online questionnaires, such as the DYFI system (Wald et al. 2011), EMSC has been one of the pioneers for citizen intensity felt reports through a set of cartoons depicting the 12 levels of the EMS98 scale (Bossu et al. 2017). Contrary to online questionnaires where intensities are derived from answers to different questions, values are user-assigned and are of an integer value. Only intensities up to 10 are considered. They compare well with the USGS DYFI responses (despite a minor correction factor) and with 
Table 3 Moment tensor solutions from various institutions determined for the 19 July 2019 mainshock. Numbers in columns strike/dip/rake denote angular parameters $\left(^{\circ}\right)$ of nodal planes 1 and 2, respectively. Source: EMSC web pages

\begin{tabular}{|c|c|c|c|c|c|c|c|c|c|c|}
\hline \multirow[t]{3}{*}{ Institution } & \multirow{3}{*}{$\begin{array}{l}\text { Magnitude } \\
(\mathrm{Mw})\end{array}$} & \multirow[t]{3}{*}{ Depth (km) } & \multirow[t]{3}{*}{ Latitude } & \multirow[t]{3}{*}{ Longitude } & \multicolumn{6}{|c|}{ Moment tensor solution } \\
\hline & & & & & \multicolumn{3}{|c|}{ Nodal plane 1} & \multicolumn{3}{|c|}{ Nodal plane 2} \\
\hline & & & & & Strike & Dip & Rake & Strike & Dip & Rake \\
\hline $\mathrm{NOA}$ & 5.2 & 13 & 38.118 & 23.530 & 274 & 29 & -100 & 106 & 61 & -84 \\
\hline GFZ & 5.3 & 13 & 38.090 & 23.480 & 272 & 50 & -107 & 119 & 43 & -68 \\
\hline INGV & 5.2 & 16 & 37.950 & 23.600 & 250 & 56 & -50 & 126 & 50 & -133 \\
\hline OCA & 5.3 & 8 & 38.150 & 23.510 & 270 & 45 & -122 & 132 & 53 & -62 \\
\hline AUTH & 5.2 & 8 & 38.140 & 23.530 & 275 & 38 & -101 & 109 & 53 & -81 \\
\hline UOA & 5.3 & 10 & 38.120 & 23.520 & 300 & 31 & -77 & 105 & 60 & -98 \\
\hline USGS & 5.3 & 16 & 38.124 & 23.509 & 275 & 29 & -103 & 110 & 61 & -82 \\
\hline
\end{tabular}

some manually derived macroseismic datasets (Bossu et al. 2017). The number of collected felt reports of intensity 7 and above is often limited immediately after the earthquake occurrence, a phenomenon called the "doughtnut effect" (Bossu et al. 2018), likely indicating existence of damage. As a consequence, cartoon felt reports can be essential to rapid situational awareness (Bossu et al. 2020).

Reported quasi real-time information ( $76 \%$ within the first hour following the earthquake occurrence) provided 451 geocoded thumbnail intensity values ranging between $1 \leq \mathrm{I}_{\mathrm{EMS} 98} \leq 8$, accompanied with descriptive felt reports and comments (Bossu et al. 2018). Most responses came from Attica, with their distribution presented in Fig. 5. With the exception of a few dubious, extreme cases of thumbnail images intensities that did not correspond to the textual description, i.e. 11 cases of $\mathrm{I}=1$ and one case of $\mathrm{I}=8$, the majority of intensities derived from the textual description in testimonies were found in agreement or close to the corresponding intensities from thumbnail images. Twenty-nine percent of intensities (red
Fig. 4 Damage photographs at Ano Liosia (top) and slope failure at Aegaleo ring road (bottom)
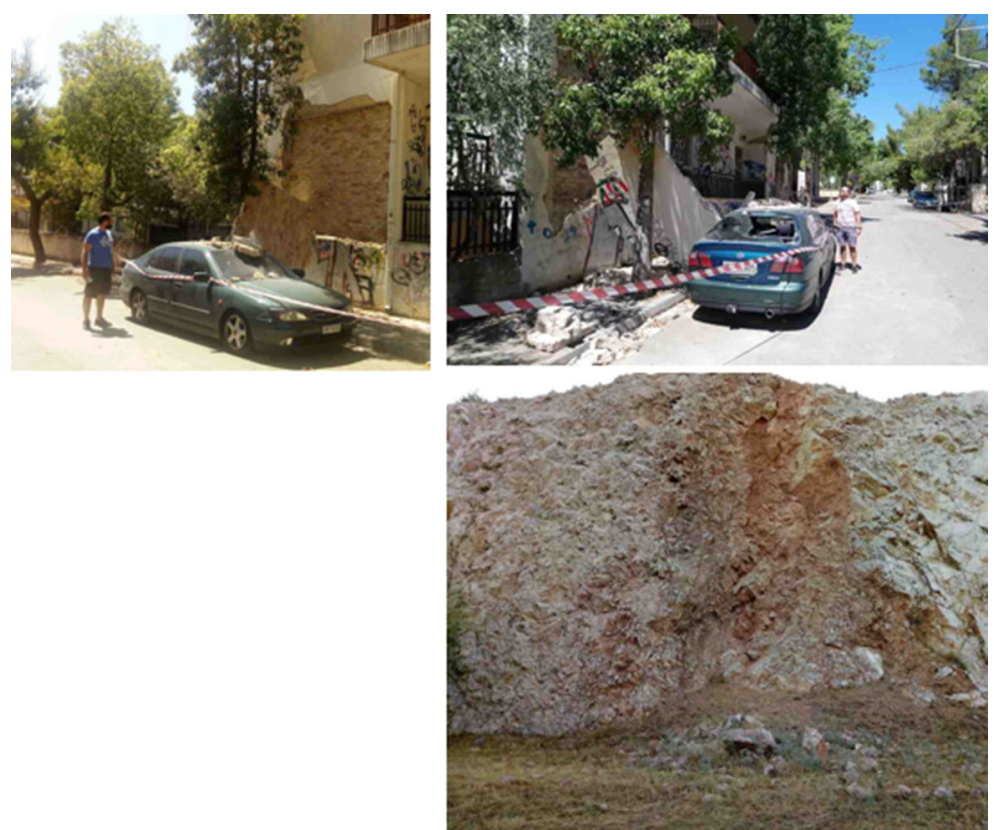


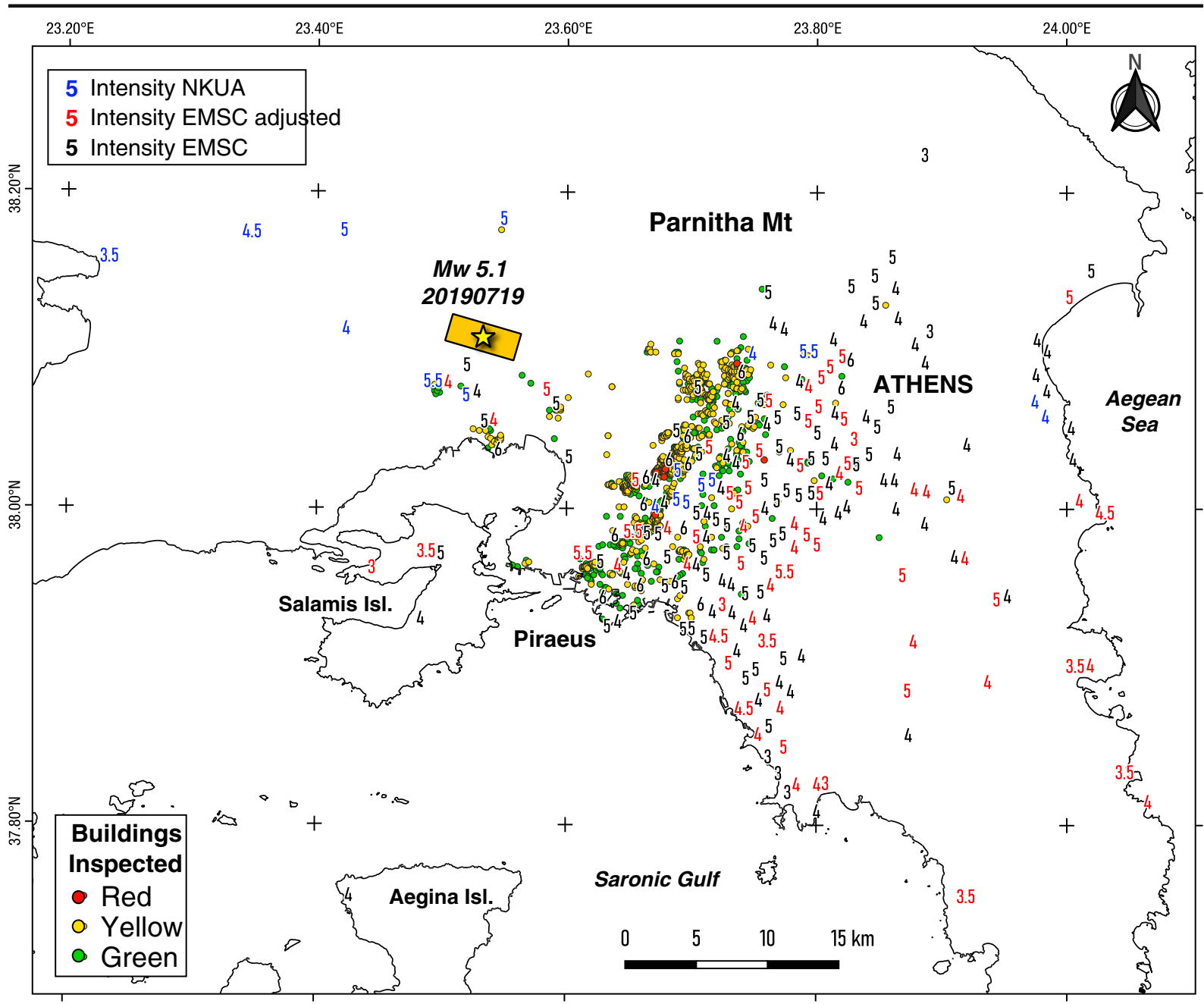

Fig. 5 Map showing macroseismic data and damage distribution due to the 19 July 2019 earthquake. Numbers represent assigned intensity values: NKUA (blue), EMSC (black), EMSC adjusted

in Fig. 5) from pictorial description needed adjustment up to one intensity degree, in order to better correspond to the textual description of the earthquake. The intensities shown in black in Fig. 5 are those with best fit between pictorial and textual description. Finally, seven cases were not taken into account, as the reported coordinates did not correspond to the locality noted in the text. The final dataset of EMSC intensities ranges within $2 \leq$ $\mathrm{I}_{\text {EMS98 }} \leq 7$ (Table 4).

\subsubsection{NKUA data}

The intensity dataset was enhanced with geocoded EMS98 intensities assigned from in situ collected questionnaire (red). Circles represent damaged ("red", "yellow", "green”) buildings distribution. The earthquake epicentre and causative fault azimuth and dimensions are also depicted

reports, following the traditional macroseismic surveys practice. In order to obtain azimuthal coverage of the macroseismic field near the epicentral area and considering that very few EMSC intensities were reported from the vicinity and to the west of the epicentre, the field team visited the villages and towns of this sparsely populated mountainous area shortly after the earthquake, as well as a number of urban suburbs in Athens metropolitan area. The team distributed and collected answers from 63 questionnaires. Macroseismic information obtained was handled as follows:

- For the remote, secluded localities to the east, west and south of the epicentre, the answers to questionnaires from several sites within them resulted in one 
Table 4 Number of macroseismic data from the various sources used in this study

\begin{tabular}{|c|c|c|c|c|c|c|}
\hline & \multirow[t]{2}{*}{ EMSC Intensities } & \multirow[t]{2}{*}{ NKUA Questionnaires } & \multicolumn{4}{|c|}{ GDAEFK Buildings inspections } \\
\hline & & & Total & Red & Yellow & Green \\
\hline Thumbnail & 451 & & & & & \\
\hline Descriptive & 451 & & & & & \\
\hline Dubious & 12 & & & & & \\
\hline Not identified & 7 & & & & & \\
\hline Traditional questionnaires & & 63 & & & & \\
\hline Photographs & & 48 & & & & \\
\hline Total buildings inspections & & & 1436 & 8 & 681 & 730 \\
\hline Undamaged & & & 25 & & & \\
\hline Not identified addresses & & & 17 & & & \\
\hline
\end{tabular}

EMS98 intensity value for each place, as insignificant discrepancies of up to half intensity degree were noted.

- For the questionnaires distributed in urban, densely populated municipalities, the addresses were geocoded, and one EMS98 intensity value was assigned for each one, similarly to the EMSC practice.

- Damage photos were also geocoded and added to the damaged buildings dataset described below, as additional evidence.

The intensity values obtained from the actions during the above-mentioned field work range within $4 \leq$ $\mathrm{I}_{\mathrm{EMS} 98} \leq 5-6$ (Fig. 5, Table 4).

\subsubsection{GDAEFK data}

Damage to buildings due to the 2019 earthquake was observed in the densely populated central, western and southern metropolitan Athens urban web. Although the population has remained broadly unchanged since 1999, the then damaged buildings have been retrofitted or some new ones have been constructed in their replacement, following the recent, more rigorous building code, issued after the 1999 earthquake (EAK 2000, amendment of 2003).

The initial and final safety inspections, according to the GDAEFK (www.yas.gr/prodlist.asp) damage categorisation, conducted by teams of engineers at 33 municipalities, reported that 8 buildings suffered heavy structural damage (permanently unusable, "red"), 681 slight-to-moderate damage (temporarily unusable, "yellow"), i.e. safe for use after interventions according to the GDAEFK (www.yas.gr/prodlist.asp) damage categorisation and 730 minor damage (usable, "green"). All buildings were geocoded using their addresses and QGIS software. In the few cases of identical street names at different municipalities, the coordinates were assigned manually using Google Earth. For a total number of 1455 geocoded damaged houses (Table A3), 25 were found undamaged by the final inspections and 17 addresses were not identified (Table 4). The general remark on damage due to the 2019 event is that the heavy or slight-to-moderately damaged and the majority of slightly affected buildings were observed in densely populated urban areas.

Following Kouskouna and Malakatas (2000), who proposed a correlation between the 3 classes ("green", "yellow", "red") of buildings' damage categorisation practice applied in Greece and the 5 EMS98 damage grades, we assessed EMS98 damage grades range for each building (Fig. 6, Table A3). Specifically, buildings with negligible to slight damage (grade 1, EMS98) are characterised as "green", those with moderate or substantial to heavy damage (grades 2-3, EMS98) as "yellow" and those with very heavy damage or destruction (grades 4-5, EMS98) as "red".

\subsubsection{Vulnerability assessment}

In certain parts of the municipal boroughs that were heavily damaged by the 1999 earthquake, some new houses have been built. The remaining building stock has not changed considerably since then, according to the vulnerability results of the 2011 census (EL.STAT., 
Sakellariou et al. 2019). At present, the building stock of the broader area presents a heterogeneity: old, vulnerable structures co-exist with new, earthquake-resistant ones. The vast majority of the constructions affected by the 2019 earthquake belongs to the first category (Fig. 6).

All damaged buildings were classified (Table A3, Fig. 6) according to the vulnerability assessment principles and vulnerability table proposed by EMS98 (Grünthal 1998). In situ damage inspection reports and photographic material were exploited for assessing vulnerability with the aid of Google Street View application, when necessary. In the damaged area, with urban metropolitan characteristics, many damaged buildings were of vulnerability class $\mathrm{B}-\mathrm{C}$ and $\mathrm{C}$, with probable range at $\mathrm{B}$ and $\mathrm{C}-\mathrm{D}$ and less probable range at $\mathrm{A}-\mathrm{B}, \mathrm{D}$ and $\mathrm{E}$.

The use of two probable classes, e.g. C-D, was necessary due to uncertainties regarding the year of construction, likely meaning that buildings have experienced an earthquake prior to 2019, thus leading to higher vulnerability. For example, a building of vulnerability class D that was struck by the 1999 earthquake, is considered as class C-D because some of these buildings have not been adequately repaired, retrofitted and maintained in order to withstand a future earthquake, which, in this case, occurred 20 years later (Grünthal 1998). For the post-1999 earthquake buildings, built according to the most recent code (EAK 2000, amendment of 2003), their vulnerability assessment is straightforward.

Vulnerability assessment has been based on the 2011 building census according to the construction period, height and construction material. From the analysis, it is evident that the majority of damaged buildings falls within classes $\mathrm{C}$ and $\mathrm{D}$.

\subsubsection{Intensity analysis}

Due to irregular geographic pattern of the assigned intensities in the entire prefecture of Attica and the damaged buildings distribution to the east, south and southeast of the epicentre, identification of any spatial clustering was considered necessary. Geographical coordinates of intensity sites and geocoded addresses of damaged buildings allowed for their grouping within grid cells, following the approach proposed by Wald et al. (1999a, 2011), who subdivided uneven ZIP code areas into regularly sized grids of a few kilometres and
Van Noten et al. (2017), who assessed intensity at $100 \mathrm{~km}^{2}$ grid cells. For the studied earthquake, the dense population distribution of Athens metropolitan allowed the selection of grid cells size at $4.957 \mathrm{~km}^{2}$, each containing more than 3 intensity values and/or at least 3 damaged buildings. With such a configuration, 33 grid cells were considered (Fig. 7). The selection of grid cells size is also justified by the 2011 census data (EL.STAT.) on population density and number of buildings per municipality area. For example, Peristeri, the most damaged municipality, which covers 2.157 grid cells, has a population of 146,743 and a total number of 28,162 buildings, according to EL.STAT. This means that in this municipality, one grid cell contains 13,053 buildings (Fig. 7 left). Figure 7 (right) presents the density distribution of Intensity Data Points (IDPs), as well as the maximum intensity derived from EMSC and NKUA reports at each cell.

Given that individual intensity values include a certain degree of inherent uncertainty, EMSC and NKUA intensities were averaged per cell, according to the EMS98 practice (Grünthal 1998; Van Noten et al. 2017), but only for those cells that contain IDPs and had no damaged buildings. No significant effects are expected due to such averaging, as IDPs values do not exceed one EMS98 degree of difference in each cell. Average intensity values were then rounded at the first decimal number. For the cells with no IDPs and with damaged buildings, EMS98 intensity was assigned by expert judgement based on the percentage of "red", "yellow" and "green" buildings according to the EMS98 practice (Grünthal 1998).

Intensity re-assignment by expert judgement was also performed for those cells containing both averaged intensity and damaged buildings. It is noted that the above-mentioned averaged intensity values are constrained by a certain level of subjectivity and correspond, in some cases, to places with negligible damage. In the cells with higher intensities (Fig. 8), observed significant, structural damage prevails, in comparison to the felt reports. However, in certain cells, it was safer to rely on the available IDPs, than to one or two houses with negligible damage. Figure 8 shows the distribution of the final intensity values assigned to all grid cells, with maximum $\mathrm{I}_{\mathrm{EMS} 98}=7.5$. For their spatial distribution, the areabased natural neighbour algorithm was applied, as it better represents the macroseismic near field (Sakkas et al. 2010). 


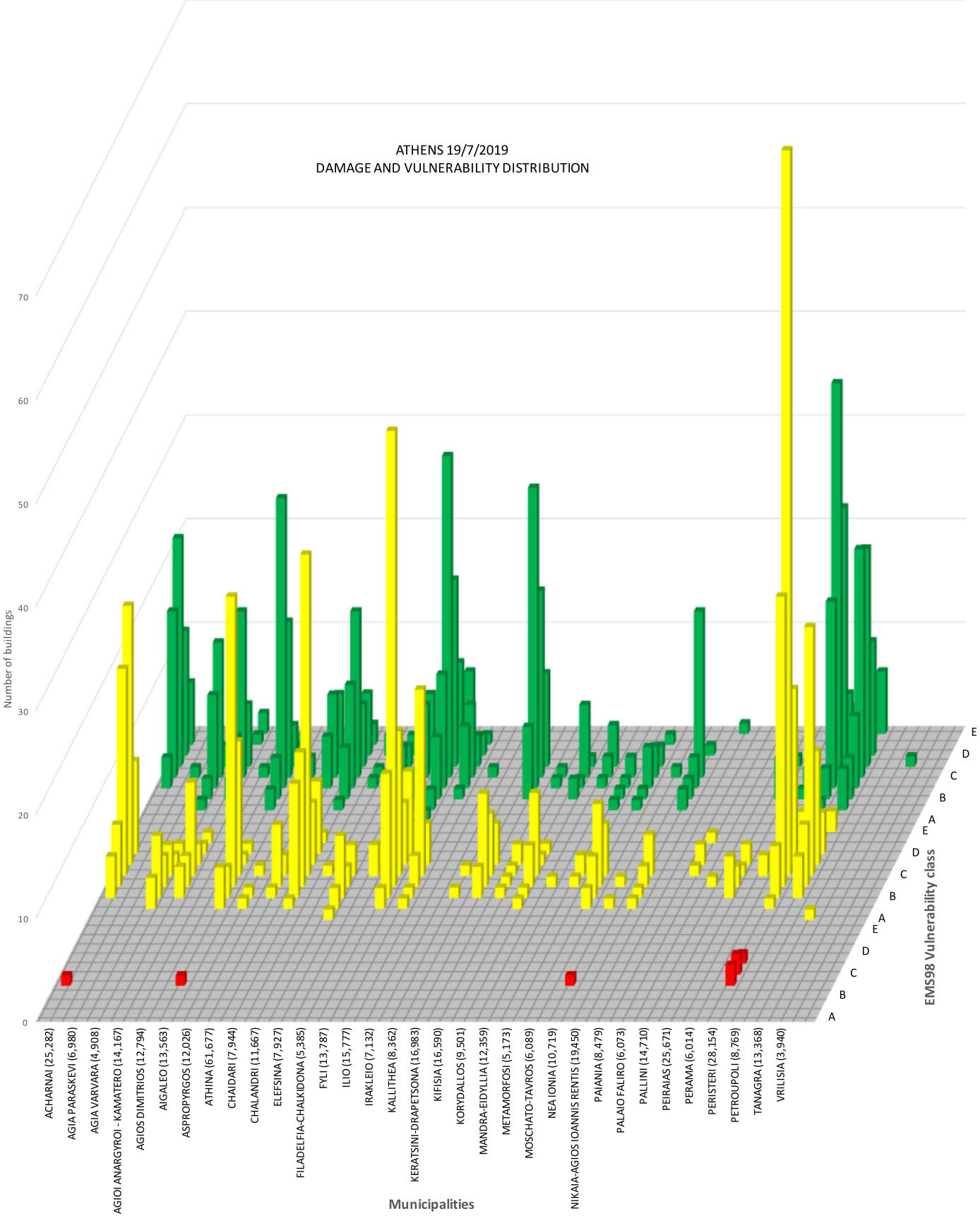

Fig. 6 Municipalities affected by the Athens 19 July 2019 earthquake: Distribution of damaged buildings per EMS98 vulnerabilaccording to the GDAEFK damage categorisation. Total number of buildings per municipality is shown in brackets 

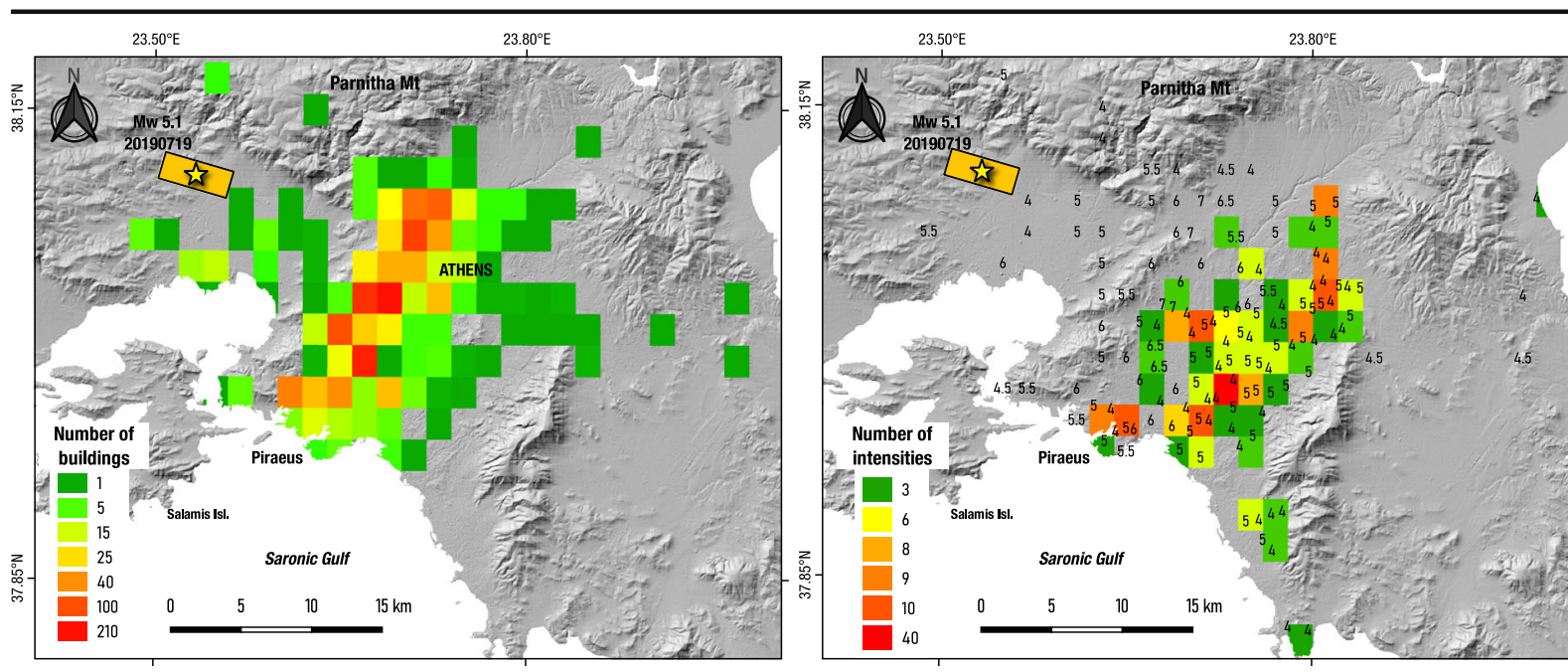

Fig. 7 Number of damaged buildings (left) and Intensity Data Points (right) included in the grid cells

\subsection{Ground motion pattern}

Ground motion parameters of the mainshock were investigated using 3 -D acceleration recordings at the permanent stations of NOA (https://accelnet.gein.noa. gr/station-information) and EPPO-ITSAK (http://www. itsak.gr/en/page/acc_network) located in the broader epicentral area. Acceleration waveforms of 27 stations (Fig. 9) were corrected for the instrument response, using SAC2000 (Goldstein et al. 2003) and the Sakkas and Sakellariou (2018) algorithm for baseline correction and filtering. Several intensity measures (IMs) were extracted (Table A4), each of which could relate to structural damage and consequently affect the macroseismic field.

As shown in Table A4 and Fig. 10, PGA ranges 3.5$414 \mathrm{~cm} / \mathrm{s}^{2}$ in the horizontal component and $2.2-232 \mathrm{~cm} /$ $\mathrm{s}^{2}$ in the vertical. PGA and PGV values are similar pattern of their distribution with distance. In the same graphs, the mean (continuous lines) and mean $+1 \sigma$ (dotted lines) of Danciu and Danciu and Tselentis (2007) and Skarlatoudis et al. (2003) empirical predictive relations of horizontal PGA and PGV values as a function of epicentral distance are also plotted. These lines were produced for site conditions stiff soil and normal faulting type. Instrumental Modified Mercalli Intensities (MMI) computed using the empirical formula proposed by Tselentis and Danciu (2008) for Greece vary between 0.3 and 8.2. However, the recordings at the nearest station (ELFA, $\sim 7 \mathrm{~km}$ ) exhibit lower values with respect to more remote stations. This pattern is similar to the distribution of macroseismic intensities
(I-EMS98) which reveal lower values in the vicinity of the epicentre (see ellipse in Fig. 10 bottom right). The highest values of measured and inferred IMs are found at distances $\geq 15 \mathrm{~km}$, at locations lying sub-parallel to the strike of the seismogenic fault. The graphs depicting the variation of the IMs with distance show significant deviations from the recorded values for distances up to $20 \mathrm{~km}$.

Given the multitude of the observations, we could reasonably presume complex geology beneath the epicentral area, leading to de-amplification of the seismic wave. Moreover, IMs at station MDFB (PGA $=414 \mathrm{~cm} /$ $\mathrm{s}^{2}, \mathrm{MMI}=8.2$ ), appear to be the maximum, somehow exaggerating the macroseismic intensity, found to be slightly greater than 6 , but at the same time located close to maximum observed intensity 7.5 and intensity 7 (Fig. 8). This localised ground motion amplification could be attributed to 2-D or 3-D effects due to the geological structure. Further research should shed light on local site effects that could likely be adverse in this region.

Lastly, predominant period of strong ground motion at small epicentral distances $(<30 \mathrm{~km})$ ranges $\sim 0.1-$ $0.5 \mathrm{~s}$ (frequencies $2-10 \mathrm{~Hz}$ ), hazardous for low-and middle-rise buildings, as is the majority of the exposed assets of Athens metropolitan area.

Site effects were investigated by means of the Horizontal-to-Vertical Spectral Ratio (HVSR) (Nakamura 1989). For each station, site amplification is approximated by the geometrical mean between horizontal and vertical Fourier spectra of the mainshock acceleration recordings. The method is based on the assumption that the vertical ground motion is not 


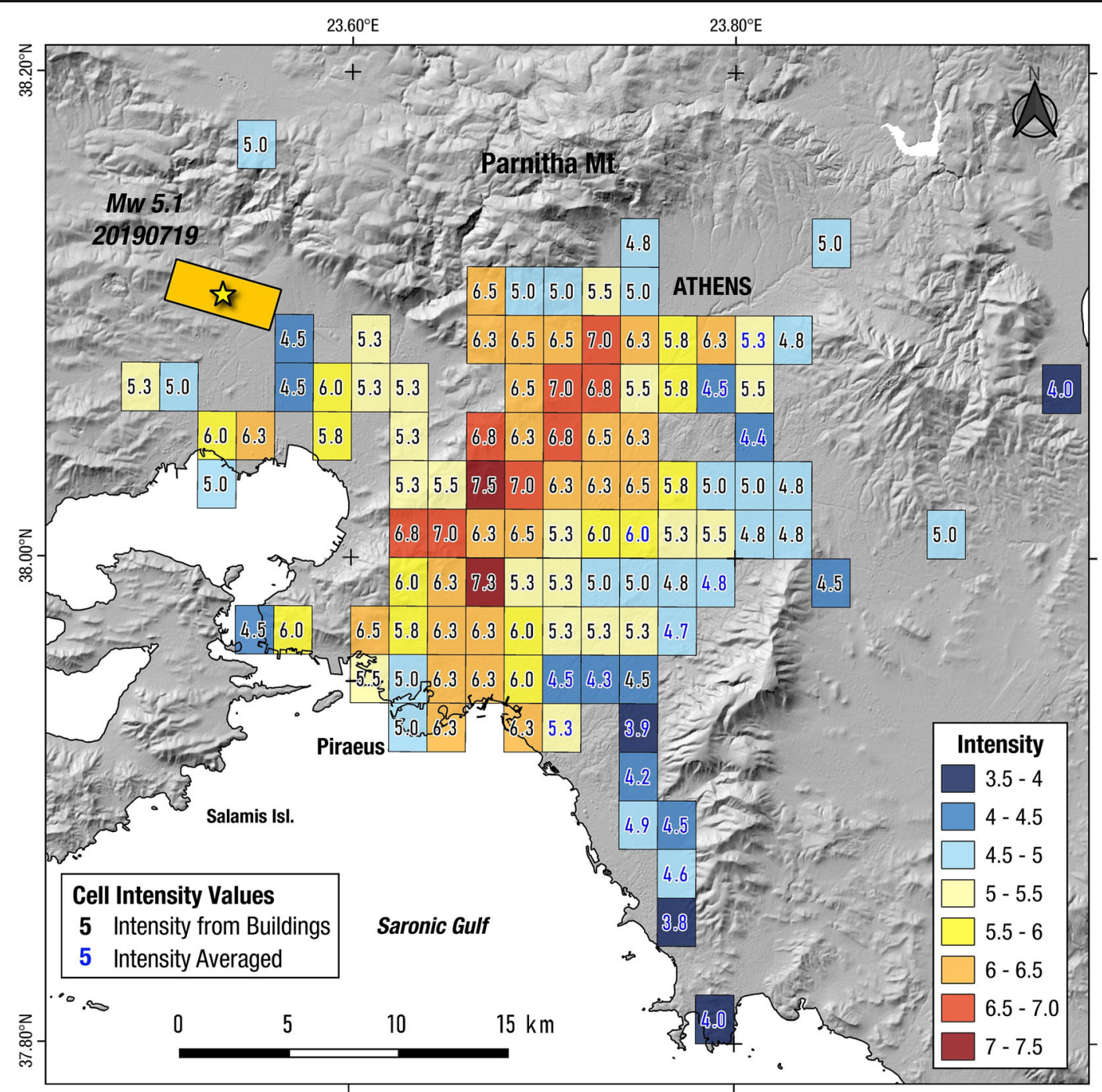

Fig. 8 Final macroseismic intensity distribution of the Athens 19 July $2019 \mathrm{M}_{\mathrm{w}} 5.1$ earthquake based on the grid cells approach and natural neighbour algorithm for their spatial distribution

amplified by the surficial layers. Therefore, the ratio of the horizontal over the vertical component represents the impedance between the uppermost layers and the underlying bedrock. It is widely accepted that the frequency of the HVSR peak correlates well with the fundamental frequency of the surficial layers (e.g. Nakamura 1989, 2000).

The HVSR method has been found to underestimate at times the actual site amplification (e.g. Bard 1999). However, several experimental studies reveal a satisfactory correlation between the HVSR and the site amplification (e.g. Rodriguez and Midorikawa 2002). It is worth noting that the HVSR method does not account for the geometry of the subsurface geology or the topography of the site (2D or 3D effects), towards which a plethora of array measurements and validation through geotechnical data is required (e.g. Kassaras et al. 2017).

HVSR curves were computed using the GEOPSY software (SESAME 2004) which allows the implementation of several processing tools, i.e. filtering, smoothing, windowing and quick visualisation of the results through a user-friendly interface. The analysis was performed over the frequency range of engineering interest $(0.5-20 \mathrm{~Hz})$. The Fast Fourier Transform (FFT) was calculated for each component of the data, and the spectra were smoothed using a logarithmic window with a smoothing factor of the order of 15-20 (Konno and Ohmachi 1998). The procedure was applied to the 


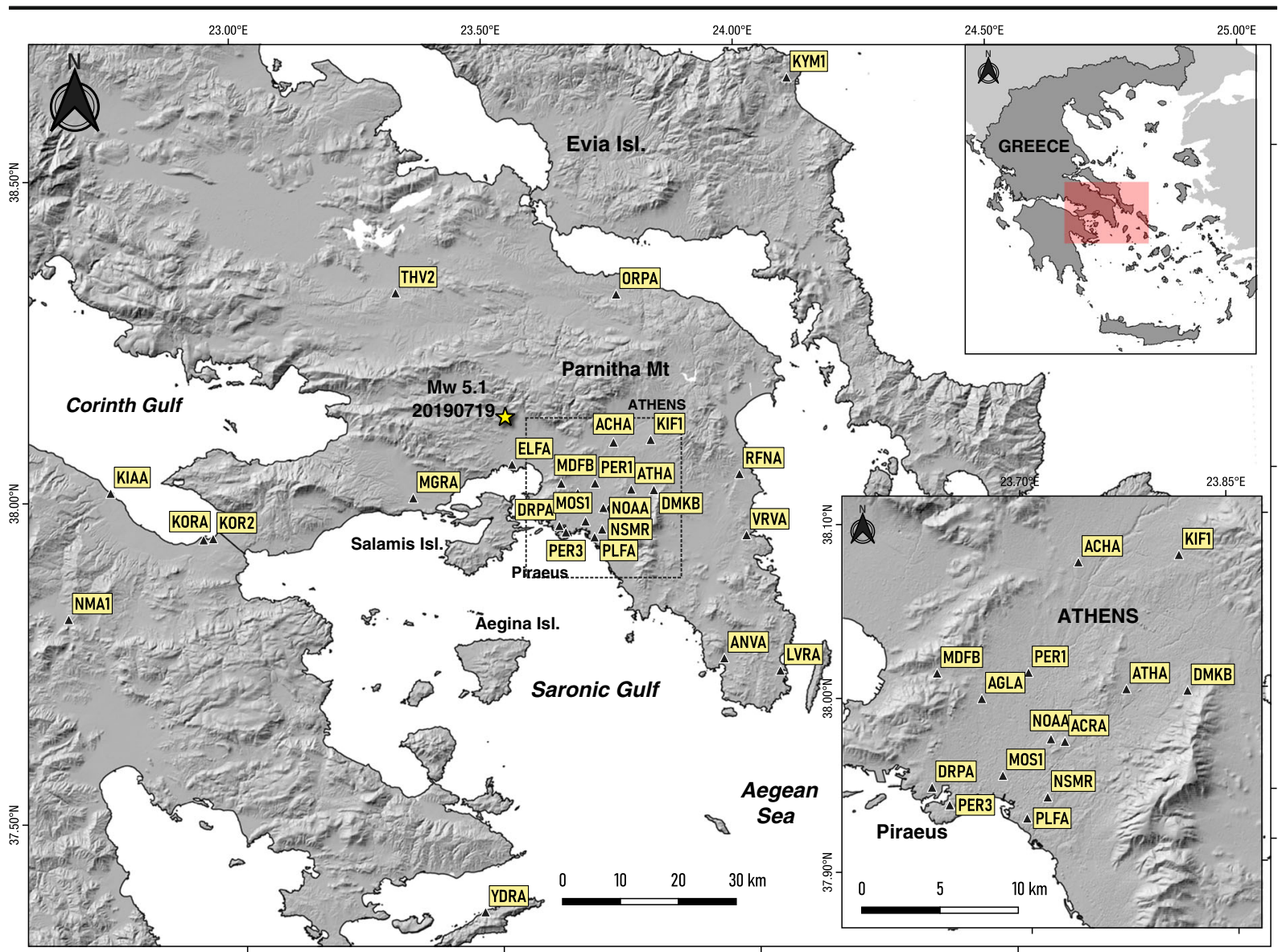

Fig. 9 The accelerometric stations of NOA (https://accelnet.gein. noa.gr/station-information) and EPPO-ITSAK (http://www.itsak. gr/en/page/acc network) used for the analysis of the strong ground motion field of the 2019 mainshock whole waveform of the mainshock at each recording accelerometric station.

The results of this analysis are shown in Fig. 11a and are listed in Table A4 in terms of predominant frequency $\left(F_{0}\right)$, i.e. the frequency that exhibits the largest amplitude, and the respective amplification ratio $\left(A_{0}\right)$. Predominant frequencies range from 0.8 to $6.8 \mathrm{~Hz}$ and amplification ratios range from 2.2 to 7.8 . Figure $11 \mathrm{a}$ presents the comparison between HVSR and Average Horizontal Predominant Frequency (AHPF) measurements for the mainshock, and Fig. 11b showcases HVSR and AHPF measurements for 6 stations located at epicentral distances $<25 \mathrm{~km}$. The observed pattern of high PGA values at PLFA and NSRM could be attributed to ground motion amplification. Interestingly, coherent predominant frequencies between HVSR and AHFP at PLFA (Fig. 11a) could support a resonance between ground motion and the soil, explaining thus the high PGA recordings of the mainshock at this station. Low PGA values in ELFA likely imply for deamplification (ELFA) due to local soil conditions. High amplification over a large period range $(1-10 \mathrm{~Hz})$ at MDFB that recorded the highest PGAs throughout the epicentral area, could likely be the result of a complex geometry of the underlying structures or topography. However, investigation of site or topographic effects is beyond the purpose of this study and more data are needed.

An important observation from the analysis of strong motion recordings is that highest IMs are distributed SE of the epicentre, at azimuths between $\mathrm{N} 100^{\circ}$ and $\mathrm{N} 150^{\circ}$, sub-parallel to the strike of the causative fault (i.e. $\mathrm{N} 110^{\circ}$ ) (Fig. 11c, Table A4), likely implying for source directivity effects.

Significant Duration (SD) has been proposed as an IM that affects damage as a function of magnitude, 

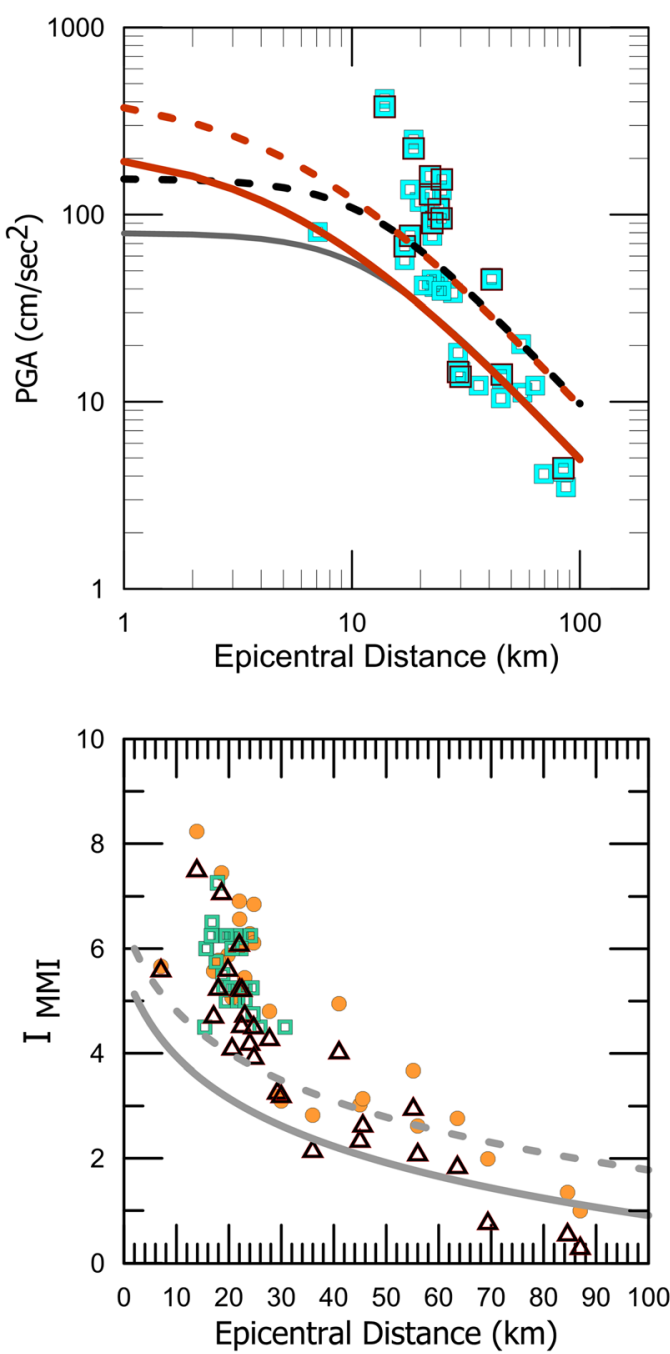

Fig. 10 Graphs showing the distribution of instrumental IMs' (PGA, PGV, MMI) and macroseismic intensities (I-EMS98) with distance for the mainshock. (see Table A3 for the exact orientation of $\mathrm{L}$ and $\mathrm{T})$. The continuous and dashed lines in the upper figures represent graphically the mean and $+1 \sigma$ empirical predictive

site-source distance, site parameters and near-source effects, by increasing the seismic demand of a system (Kempton and Stewart 2006). It is based on the integral of square of the acceleration, i.e. accumulation of seismic energy in the accelerograms, in terms of $5-95 \%$ built up of the Arias intensity (Bommer and Martinez-Pereira 1996). The azimuthal distribution of measured SD indicates that shorter SDs are concentrated towards the SE (Fig. 12). Figure 13 shows the spatial distribution of PGA and its empirical MMI derivative. Seismic energy is concentrated to the SE of the epicentre of the mainshock, whereas ground motions appear weak elsewhere.
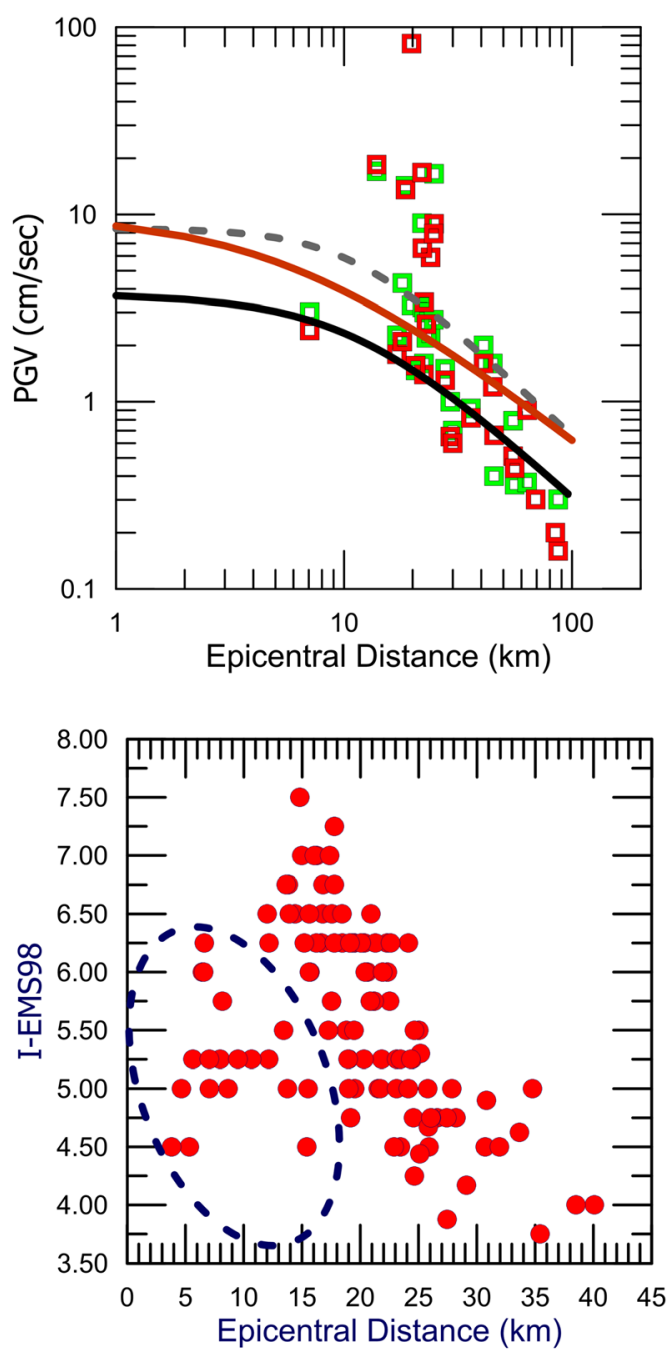

relations of horizontal PGA and PGV of Danciu and Danciu and Tselentis (2007) and Skarlatoudis et al. (2003), respectively. In the lower part the graphs depict the distribution of Macroseismic Intensity with distance. The mean and $+1 \sigma$ relation of Papazachos and Papaioannou (1997) are also shown

\section{Results and discussion}

\subsection{Fault model}

The close relation of the 2019 to the 1999 event is apparent through their overlap observed in the spatial distribution of their aftershocks (Fig. 14). The area covered by the 2019 aftershocks (red dots) is considerably smaller, indicating that the activated western fault segment is smaller than the 1999 eastern one, in accordance with moment magnitude difference. The 2019 aftershock distribution (154 events) is clustered around the 2019 mainshock, and mostly towards the north and 
AHPF vs HVSR
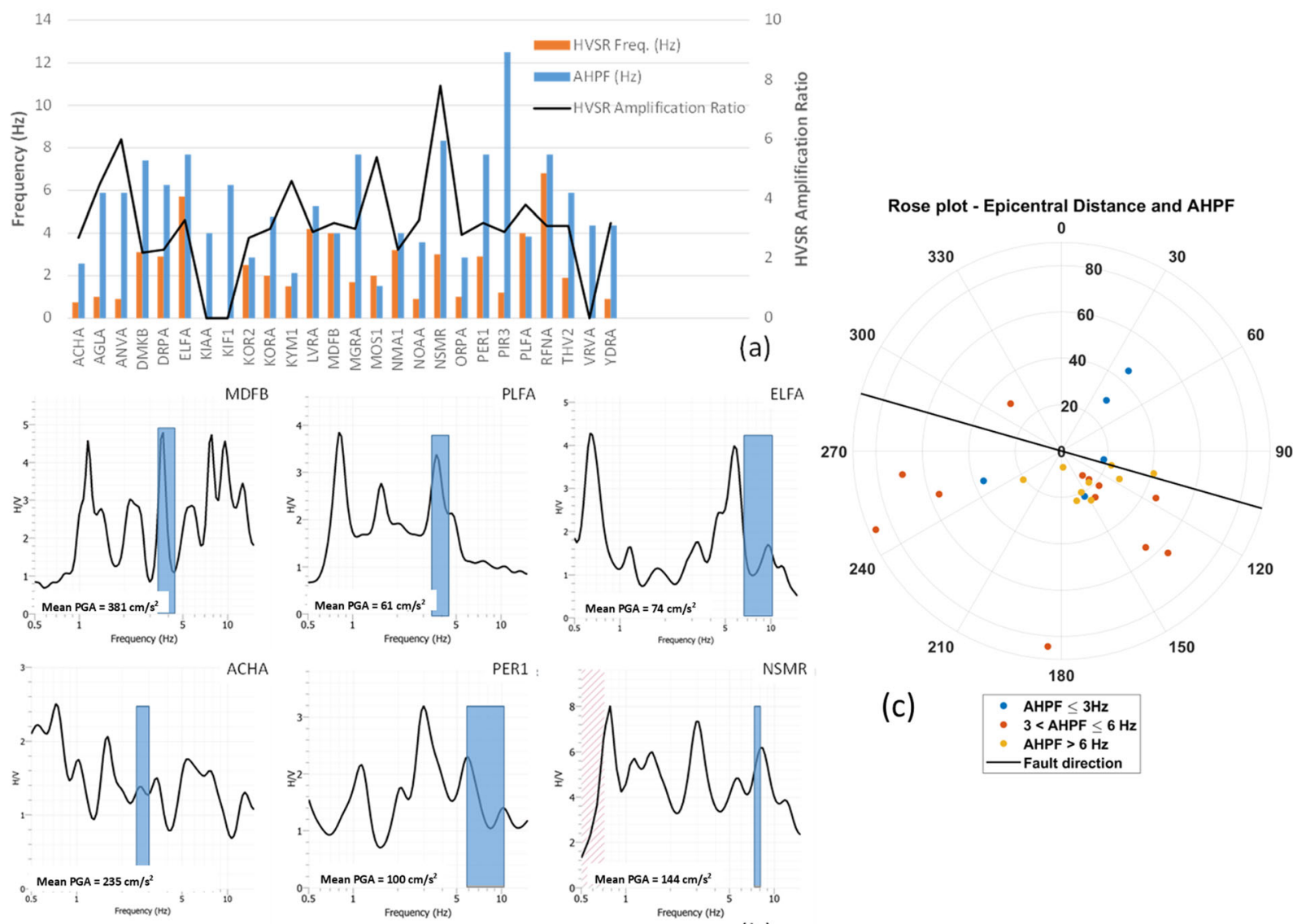

(c)

(b)

Fig. 11 a Synopsis of the HVSR measurements with respect to the Average Horizontal Predominant Frequency (AHPF). b Comparisons between AHPF (blue bars) and HVSR (black solid lines)

updip. A smaller cluster formed a few $\mathrm{km}$ to the SE of the mainshock. Moreover, our field survey did not provide evidence of any surface breaks due to this earthquake, meaning that the rupture did not reach the surface. This finding is in accordance with the estimated focal depth $(10.6 \mathrm{~km})$ from relocation. We note that published fault maps for Parnitha region (Lekkas 2001; Ganas et al. 2004, 2005; Deligiannakis et al. 2018) do not report an active fault trace in the surface projection of the seismic fault. It is therefore concluded that the 2019 earthquake ruptured a southdipping, blind normal fault at the north-western edge of Thriassion plane (Fig. 15), about $5 \mathrm{~km}$ to the north of Magoula.

A uniform-slip fault model indicates that a rectangle of 5-km length $( \pm 1 \mathrm{~km})$ by $4 \mathrm{~km}$ width $( \pm 1 \mathrm{~km})$ may fit the size of the seismic source. The estimated size is measurements, to examine possible relation of ground motion to soil resonance. $\mathbf{c}$ Rose plot of epicentral distance for each station and AHPF

based on a forward Okada-type dislocation modelling assuming elastic half-space (Okada 1985) using the relocated mainshock source parameters, the fault plane solution and the Wells and Coppersmith (1994) empirical relationship between fault-length and magnitude and fault-width and magnitude, respectively. We put forward two models, one with the hypocenter coinciding with the slip-centroid (2019-1 in Fig. 15) and a second model with the hypocenter at the middle of the bottom-fault line as suggested by the relocated aftershocks (at 10.6 km; Fig. 2, section a1-a2). Regarding the strike/dip of the fault plane, we adopted the values from seismology (Table 1), therefore the orientation of the source is ESE-WNW $\left(\mathrm{N} 106^{\circ} \mathrm{E}\right)$ and the dip-angle is $61-52^{\circ}$ towards south. The top-fault depth in the case of the model 2019-1 is $9 \pm 0.2 \mathrm{~km}$, while for case 2019-2 is $7.2 \pm 0.2 \mathrm{~km}$, respectively. The respective solutions 


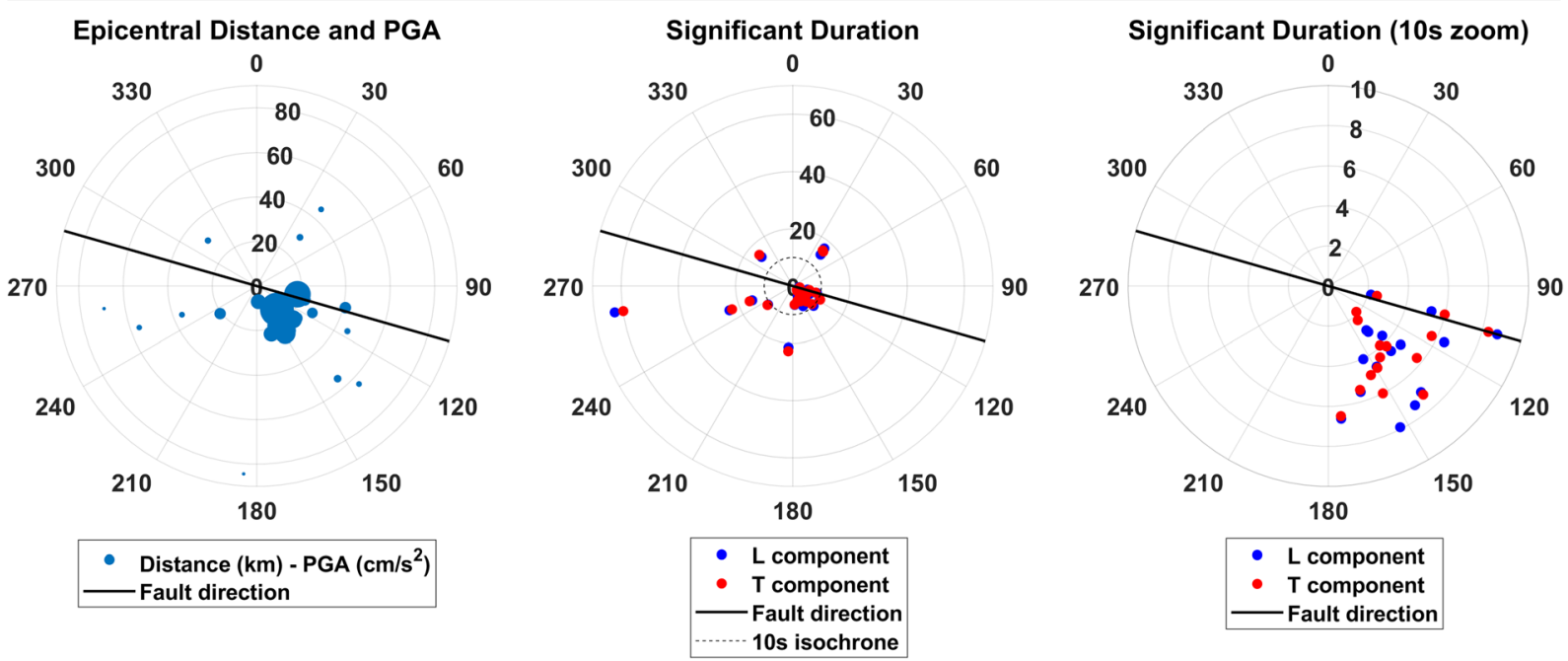

Fig. 12 Azimuthal distribution of significant duration (5-95\% of Arias Intensity)

are presented as surface projections of the two fault models in Fig. 15.

This fault geometry and location inside the upper crust of Parnitha resembles greatly the 1999 seismic source geometry, as it was determined from inversion of geodetic data (InSAR displacements; Kontoes et al. 2000, Atzori et al. 2008). The strike/dip angles for the 1999 fault plane were determined to $116^{\circ} / 54^{\circ}$ (Kontoes et al. 2000; main fault patch) and $110^{\circ} / 60^{\circ}$ (Atzori et al. 2008) respectively. Indeed, the two 2019 fault planes (2019-1 and 2019-2) do overlap with the 1999 modelled ruptures (Fig. 15), mostly towards the western termination of it. The westernmost slip patches of the 1999 rupture were determined at a depth of $10 \mathrm{~km}$ (Atzori et al. 2008) which is close to the top-fault estimates of this study $(7-9 \mathrm{~km}$; also considering the ERZ of $1.3 \mathrm{~km}$ of the relocated mainshock), while the two sets of ruptures partially overlap (Fig. 15). Therefore, it is suggested that the 2019 earthquake ruptured the Parnitha normal fault and it can be considered as the western continuation of the 1999 event. The examination of the alternative locations of the 1999 fault plane provided by seismological data (e.g. Louvari and Kiratzi 2001; Baumont et al. 2004) also tend to support the hypothesis that the 2019 rupture was coplanar to the 1999 one, however, the derived slip models are sensitive to the location \& depth of the 1999 mainshock which is still subjected to debate because of the scarcity of near-field stations (at that time).

We note that the 2019 rupture is located inside the area of the 1999 fault plane that experienced 5-20 cm of afterslip in the period 1999-2001 (Atzori et al. 2008), yet it recovered within a period of 20 years and ruptured again in 2019. We suggest this occurred because( a) Coulomb stress transfer towards the west of the 1999 rupture (Atzori et al. 2008) that advanced time-towardsfailure of the western segment, (b) tectonic loading and (c) shear zone interactions in the lower crust that can lead to earthquake clustering along normal faults (Cowie et al. 2013; Copley et al. 2018).

3.2 Macroseismic intensity distribution, strong motion pattern and directivity effects

The macroseismic field shows an eclectic pattern ESE of the epicentre, in perpendicular direction to the strike of the inferred fault (Fig. 8). In the vicinity of the epicentre, $(D<10 \mathrm{~km})$, intensities only up to 5.2 were reported, with very few isolated cases of negligible damage. However, structural damage and maximum intensity $I_{\max } 7.5$ was observed at larger distances between 12 and $15 \mathrm{~km}$ east and ESE of the epicentre, in consistency with the instrumental IMs values distribution, which also appear increased towards this direction. During the 1999 M6.0 earthquake, intensity values 8 and 9 were assigned at larger epicentral distances inside the Athens basin, while intensities 7 were estimated near the epicentre (Anastasiadis et al. 1999). The SE spatiotemporal propagation of the 19 July 2019 aftershock sequence was observed by Kapetanidis et al. (2020).

Increase of effects eastward was also observed during the Ms6.7 earthquake on 24 February 1981 at the eastern Gulf of Corinth, which caused severe damage in its broader epicentral area (Tilford et al. 1985). Its isoseismal map (Fig. 16; Kouskouna et al. 2020) 
Fig. 13 Spatial distribution of PGA (top-panel), PGV (middlepanel) and MMI (bottom-panel) for the 2019 mainshock. MMI contours were computed by QGIS tools
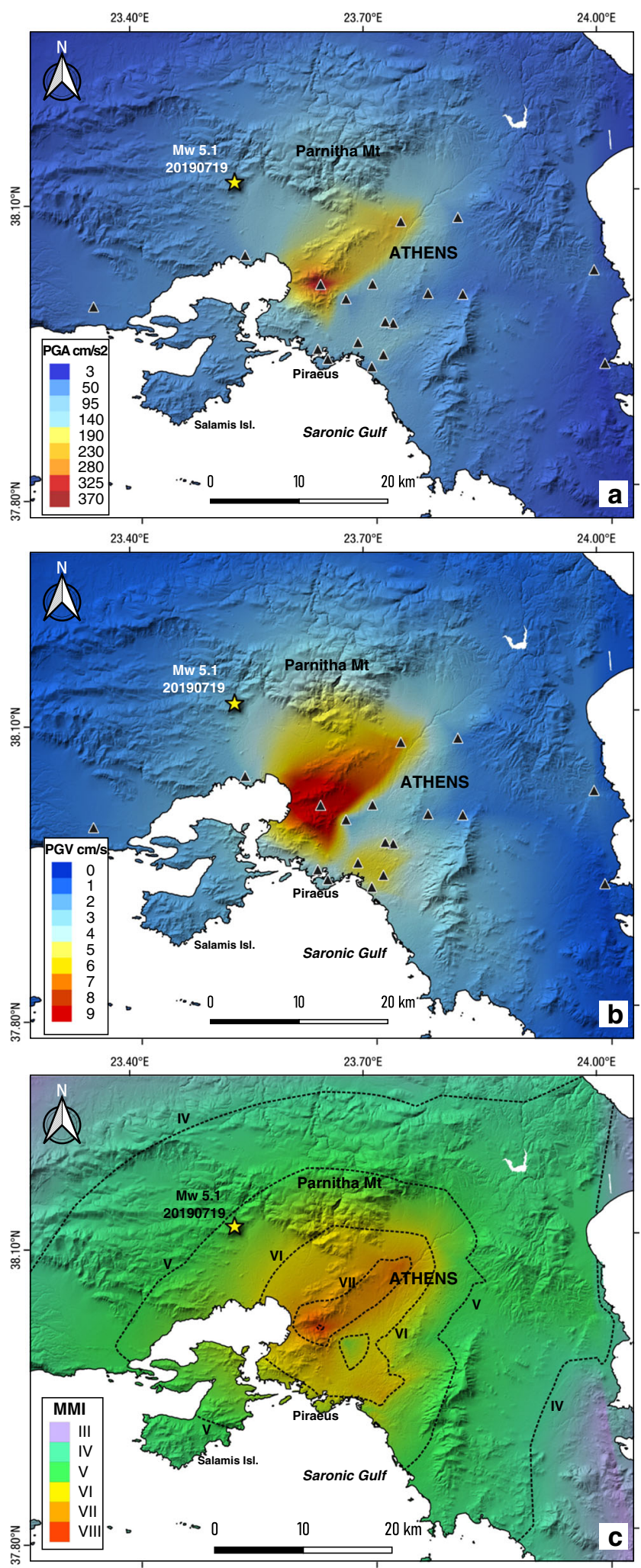


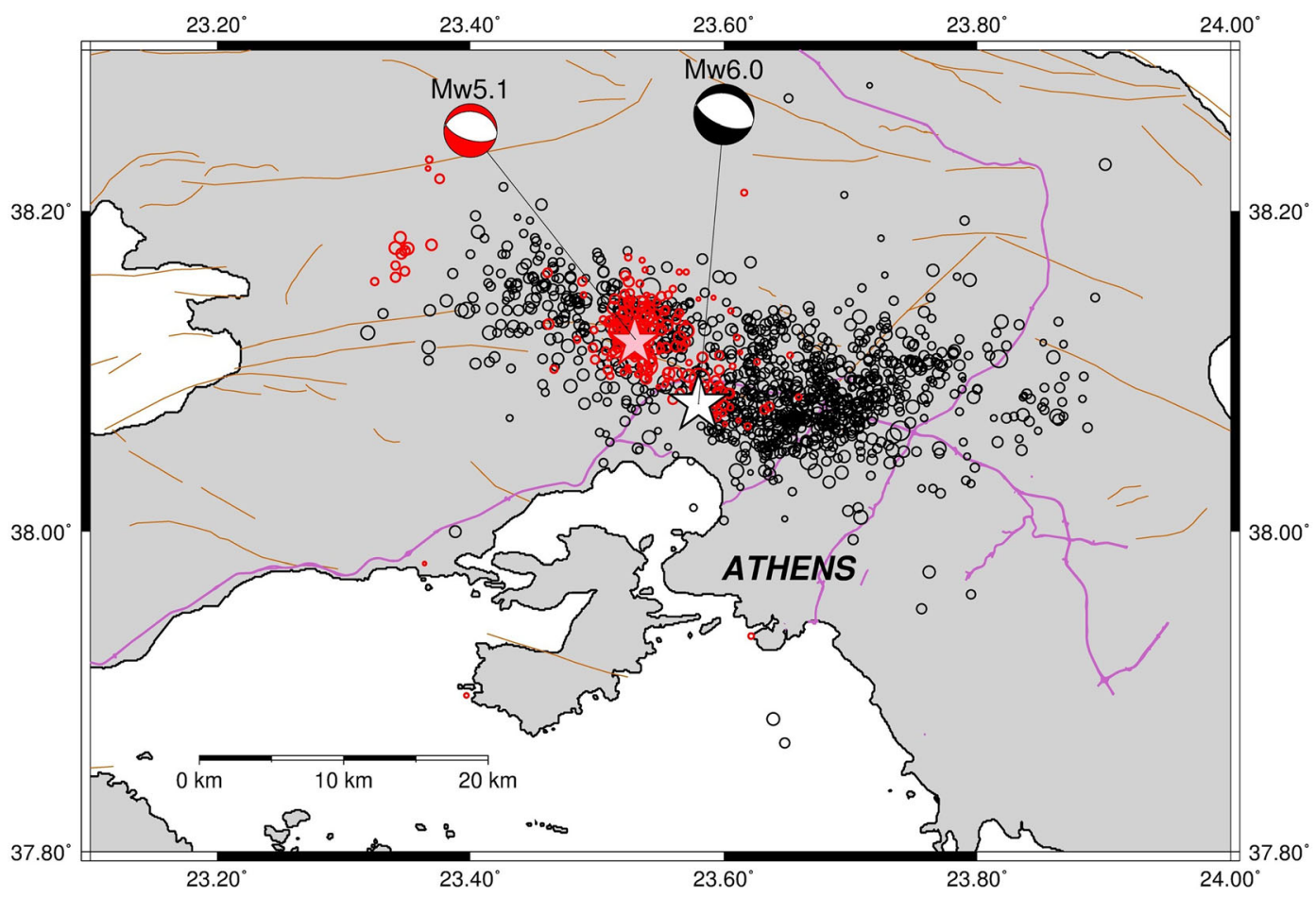

Fig. 14 Relocated aftershock distributions of the 2019 and 1999 Athens earthquakes. Solid stars are mainshock epicentres

indicates elongation of isoseismals towards $\sim \mathrm{E}-\mathrm{W}$ direction, in agreement with the strike of the causative fault, while highest intensity values, of the order of VII and VIII were concentrated to the east of the epicentre, indicating that most of the energy was propagated towards this direction. As stated by Tilford et al. (1985), soil conditions also played significant role, as the highest intensities were observed at sites located on soft soils. Nonetheless, the pattern could be likely associated with eastward source propagation.

Macroseismic intensities 6 and 7, as well as slope failure effects were observed along the western Kifissos riverbeds. This area, dominated by thick fluvial and sedimentary formations, belongs to a major tectonic zone that separates Western from Eastern Attica (Lekkas 2001; Fig. A1). During the Athens 1999 Mw6.0 earthquake, structural damage was concentrated to the east of the epicentre, and along Kifissos riverbeds where intensity values reached IX. Figure 13 shows a similar qualitative pattern for the 2019 earthquake. This pattern has been explained as due to local topography and soil effects (Gazetas et al. 2002). Moreover, significant duration of the 1999 mainshock was found to be shorter towards the east of the mainshock (Table A5), in agreement with Papadimitriou et al. (2002) and
Baumont et al. (2004) and likely the effect of an eastward propagation of the fault rupture.

\section{Conclusions}

The analysis of strong motion recordings of the mainshock at 27 permanent stations of NOA and EPPO-ITSAK indicated systematically larger excitations to the SE of the epicentre, while site effects, observed by HVSR analysis, were likely the cause for observed irregularities at both strong motion recordings and at damaged buildings distribution. Maximum intensity 7.5 was observed parallel to the fault strike. In general, higher intensities were distributed in a direction perpendicular to the fault strike, along the Kifissos river (Fig. 8 and A1). The grid cell approach allowed an improved identification of the macroseismic field pattern and correlation with strong motion data. Damage due to near-field strong motion is mainly related to the long-period wavefield. The peak ground velocity (PGV) is one of the most important parameters reflecting the intensity of near-field ground motion, since it grasps the long-period wavefield with respect to the PGA (e.g. Wald et al. 1999b). 


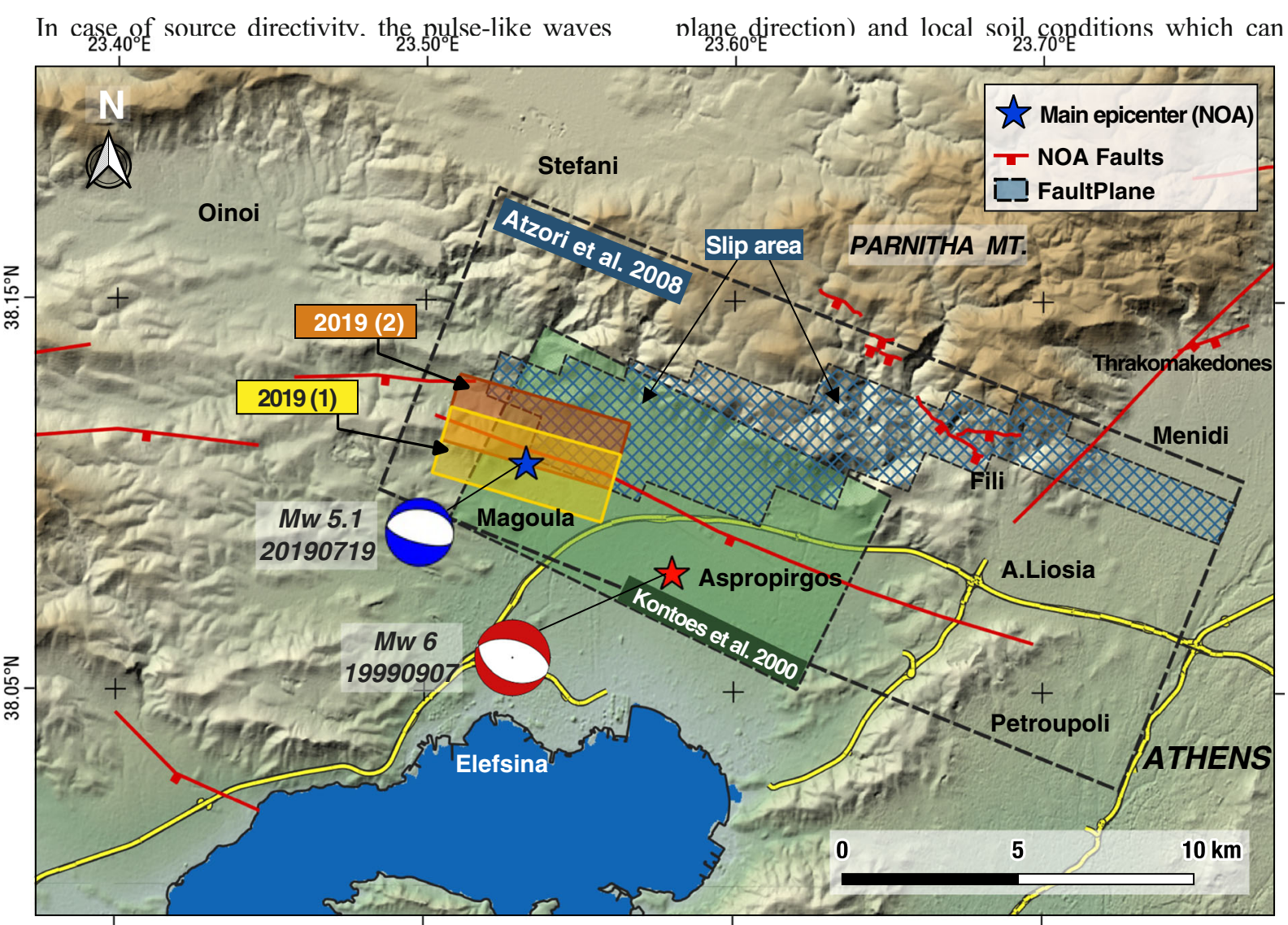

Fig. 15 Relief map showing surface projections of seismic fault planes for the 2019 and 1999 Athens earthquakes. Yellow rectangles represent the 2019 rupture planes; bright with hypocentre at fault centre, dark with hypocentre and fault bottom edge. Green and open rectangles indicate the Kontoes et al. (2000) and Atzori

arrive early at the recording stations (Baker 2007). Time histories are affected by the Doppler effect with respect to the orientation of the station, i.e. the energy of the rupture radiation is stacked at the front end of the rupture, while the time it takes for the energy to reach the back end of the rupture is delayed. PI was found $>0.85$ as an early arrival in recordings at stations located SE of the epicentre, thus, the velocity histories of these stations are characterised by forward directivity. Significant durations, measured as the time of 5-95\% Arias intensity build-up, were found shorter to the SE of the epicentre, corresponding to high-amplitude acceleration, while the large rise times on the other azimuths correspond to low-amplitude waveforms. Therefore, it is reasonable to presume a SE source propagation for the 19 July 2019 mainshock. Thereafter, radiation pattern (i.e. largest S- and Love-wave amplitudes in the fault- et al. (2008) rupture planes, respectively. The blue, hatched rectangles indicate the slip patches of Atzori et al. (2008). Beachballs indicate moment tensor solutions for both events (compressional quadrants are shaded)

affect seismic energy could play an additional role.

A cutoff of seismic energy occurs east of Aegaleo Mt., recognised as a feature that imposed a stopping phase in the time histories of the 1999 (Papadimitriou et al. 2002) and 2019 earthquakes. If this is the case, Aegaleo Mt. is likely the shield of Athens metropolis from local seismic sources from the west. Alternatively, large excitations along the eastern foot of Aegaleo Mt. are possibly due to site-effects emerged from the alluvial formations alongside the banks of Kifissos River, where heaviest damage occurred during the two events (e.g. Pomonis 2002; Kouskouna et al. 2019). The site effects hypothesis is supported by high intensities 6-7.5 and slope failure effects along the western Kifissos riverbeds during the current event, and by similar pattern of high intensities observed during the 1981 Alkyonides and the 1999 Athens earthquakes. 


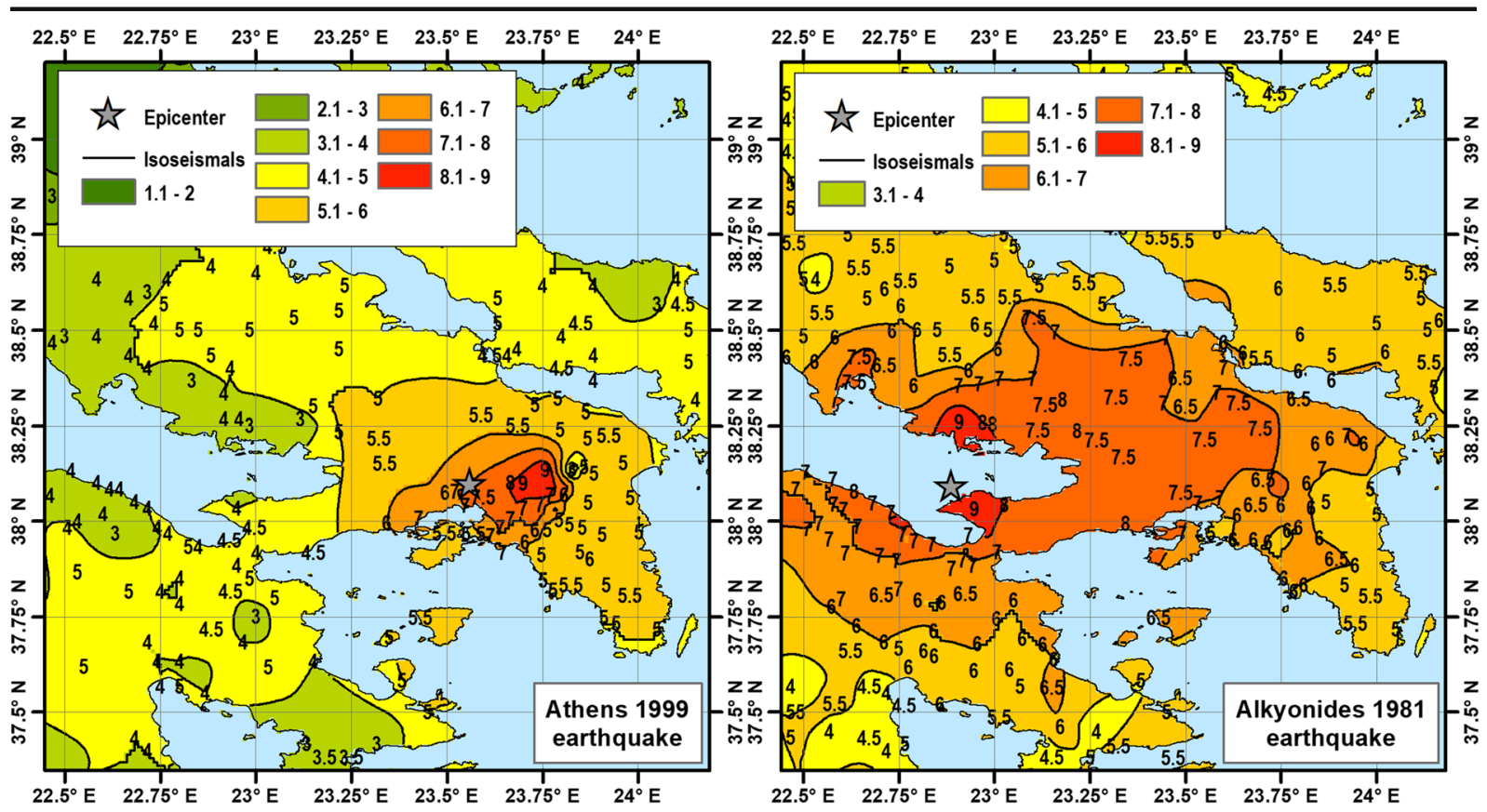

Fig. 16 Intensity distribution and isoseismal lines. Left: 7th September 1999 Athens, Right: 24th February 1981 Alkyonides earthquakes (Kouskouna et al. 2020)

The 2019 rupture is located inside an area at the western part of the 1999 fault plane that experienced 5-20 cm of afterslip during the period 1999-2001.

Supplementary Information The online version contains supplementary material available at https://doi.org/10.1007/s10950021-09990-3.

Acknowledgements EMSC would like to thank the Fondation d'entreprise SCOR pour la science for its support. This article was partially funded by the European Union's Horizon 2020 research and innovation programme under grant agreement RISE No 821115 and grant agreement TurnKey No. 821046. Opinions expressed in this paper solely reflect the authors' view; the EU was not responsible for any use that may be made of information it contains. We acknowledge partial funding support by the Special Account for Research Grants of the National and Kapodistrian University of Athens.

We used data from the HL (Institute of Geodynamics, National Observatory of Athens, doi: https://doi.org/10.7914/SN/HL), HA (National and Kapodistrian University of Athens, doi: https://doi. org/10.7914/SN/HA), and HI (Institute of Engineering Seismology and Earthquake Engineering, doi: https://doi. org/10.7914/SN/HI) networks. We acknowledge I. Kalogeras for providing NOA strong ground motion data. We used strong ground motion data from the EPPO-ITSAK strong motion network. Census data were provided by the Hellenic Statistical Authority (EL.STAT.). Intensity and strong motion Figures were prepared using QGIS Geographic Information System, Open Source Geospatial Foundation Project, http://qgis.osgeo.org. Figure 7 was prepared using the Generic Mapping Tool (GMT) software by Wessel et al. (2013).
A. Ganas and Ch. Papaioannou acknowledge partial support of this work by the project HELPOS - Hellenic System for Lithosphere Monitoring" (MIS 5002697), which is implemented under the Action "Reinforcement of the Research and Innovation Infrastructure", funded by the Operational Programme ""Competitiveness, Entrepreneurship and Innovation"' (NSRF 2014-2020) and co-financed by Greece and the European Union (European Regional Development Fund).

Funding This article was partially funded by the European Union's Horizon 2020 research and innovation programme under grant agreement RISE No. 821115 and grant agreement TurnKey No. 821046.

Open Access This article is licensed under a Creative Commons Attribution 4.0 International License, which permits use, sharing, adaptation, distribution and reproduction in any medium or format, as long as you give appropriate credit to the original author(s) and the source, provide a link to the Creative Commons licence, and indicate if changes were made. The images or other third party material in this article are included in the article's Creative Commons licence, unless indicated otherwise in a credit line to the material. If material is not included in the article's Creative Commons licence and your intended use is not permitted by statutory regulation or exceeds the permitted use, you will need to obtain permission directly from the copyright holder. To view a copy of this licence, visit http://creativecommons.org/licenses/by/4.0/. 


\section{References}

Anastasiadis AN, Demosthenous M, Karakostas CH, Klimis N, Lekidis B, Margaris B, Papaioannou CH, Papazachos C, Theodulidis N (1999) The Athens (Greece) earthquake of September 7, 1999: preliminary report on strong motion data and structural response. MCEER online Rpt http://mceer. buffalo.edu/research/greece090799/

Atzori S, Manunta M, Fornaro G, Ganas A, Salvi S (2008) Postseismic displacement of the 1999 Athens earthquake retrieved by the differential interferometry by synthetic aperture radar time series. J Geophys Res 113:B09309. https://doi.org/10.1029/2007JB005504

Baker JW (2007) Quantitative classification of near-fault ground motions using wavelet analysis. Bull Seismol Soc Am 97: 1486-1501. https://doi.org/10.1785/0120060255

Bard P-Y (1999) Microtremor measurements: a tool for site effect estimation? In: Irikura K, Kudo K, Okada H, Sasatami T (eds) The effects of surface geology on seismic motion. Balkema, Rotterdam, pp 1251-1279

Baumont D, Scotti O, Courboulex F, Melis N (2004) Complex kinematic rupture of the Mw 5.9, 1999 Athens earthquake as revealed by the joint inversion of regional seismological and SAR data. Geophys J Int 158:1078-1087

Bommer J, Martinez-Pereira A (1996) The prediction of strongmotion duration for engineering design. Proc. 11 WCEE, Elsevier science, 84, ISBN 0080428223

Bossu R, Landès M, Roussel F, Steed R, Mazet-Roux G, Martin SS, Hough S (2017) Thumbnail-based questionnaires for the rapid and efficient collection of macroseismic data from global earthquakes. Seismol Res Lett 88:72-81. https://doi. org/10.1785/0220160120

Bossu R, Roussel F, Fallou L, Landès M, Steed R, Mazet-Roux G, Dupont A, Frobert L, Petersen L (2018) LastQuake: from rapid information to global seismic risk reduction. Int $\mathrm{J}$ Disaster Risk Reduct 28:32-42. https://doi.org/10.1016/j. ijdrr.2018.02.024

Bossu R, Fallou L, Landès M, Roussel F, Julien-Laferrière S, Roch J, Steed R (2020) Rapid public information and situational awareness after the November 26, 2019, Albania earthquake: lessons learned from the LastQuake system. Front Earth Sci 8:235. https://doi.org/10.3389/feart.2020.00235

Chousianitis K, Ganas A, Evangelidis CP (2015) Strain and rotation rate patterns of mainland Greece from continuous GPS data and comparison between seismic and geodetic moment release. J Geophys Res Solid Earth 120:3909-3931. https://doi.org/10.1002/2014JB011762/full

Copley A, Grützner C, Howell A, Jackson J, Penney C, Wimpenny S (2018) Unexpected earthquake hazard revealed by Holocene rupture on the Kenchreai Fault (central Greece): implications for weak sub-fault shear zones. Earth Plan Sc Lett 486:141154. https://doi.org/10.1016/j.epsl.2018.01.014

Cowie P, Scholz C, Roberts GF, Walker GP, Steer P (2013) Viscous roots of active seismogenic faults revealed by geologic slip rate variations. Nat Geosci 6:1036-1040. https://doi.org/10.1038/ngeo1991
Danciu L, Tselentis G-A (2007) Engineering ground-motion parameters attenuation relationships for Greece. Bull Seismol Soc Am 97:162-183. https://doi.org/10.1785/0120040087

Deligiannakis G, Papanikolaou ID, Roberts G (2018) Fault specific GIS based seismic hazard maps for the Attica region, Greece. Geomorphology 306:264-282. https://doi. org/10.1016/j.geomorph.2016.12.005

EAK (2000, amendment of 2003) Greek Antiseismic Code. Earthquake Planning and Protection Organization, Athens https://www.oasp.gr/node/8

Ganas A, Papadopoulos GA, Pavlides SB (2001) The 7th September 1999 Athens 5.9Ms earthquake: remote sensing and digital elevation model inputs towards identifying the seismic fault. Int J Remote Sens 22:191-196

Ganas A, Pavlides SB, Sboras S, Valkaniotis S, Papaioannou S, Alexandris GA, Plessa A, Papadopoulos GA (2004) Active fault geometry and kinematics in Parnitha Mountain, Attica. Greece J Struct Geol 26:2103-2118

Ganas A, Pavlides S, Karastathis V (2005) DEM-based morphometry of range-front escarpments in Attica, central Greece, and its relation to fault slip rates. Geomorphology 65:301-319

Gazetas G., Kallou P.V., Psarropoulos P. N (2002) Topography and soil effects in the MS 5.9 Parnitha (Athens) earthquake: the case of Adámes. Nat Hazards, 27: 133-169. https://doi. org/10.1023/A:1019937106428

Goldstein P, Dodge D, Firpo M, Minner L (2003) SAC2000: Signal processing and analysis tools for seismologists and engineers. In: Lee WHK, Kanamori H, Jennings PC, Kisslinger C (eds) Invited contribution to "The IASPEI International Handbook of Earthquake and Engineering Seismology". Academic Press, London

Grünthal G (1998) European Macroseismic Scale 1998 (EMS98). European Seismological Commission, Working Group Macroseismic Scale, Cahiers du Centre Européen de Géodynamique et de Séismologie 15, Luxembourg

Husen S, Kissling E, Deichmann N, Wiemer S, Giardini D, Baer M (2003) Probabilistic earthquake location in complex 3-D velocity models: application to Switzerland. J Geophys Res 108. https://doi.org/10.1029/2002JB001778

ITSAK (2019) The M5.3 NW Attica earthquake of 19/7/2019 preliminary report, ITSAK res. Unit, Thessaloniki, 9pp, http://www.itsak.gr/uploads/news/earth-quake_reports/EQ Attica_2019-07-19_M5.3_report_v02.pdf

Kapetanidis V, Karakonstantis A, Papadimitriou P, Pavlou K, Spingos I, Kaviris G, Voulgaris N (2020) The 19 July 2019 earthquake in Athens, Greece: a delayed major aftershock of the $1999 \mathrm{M}_{\mathrm{w}} 6.0$ event, or the activation of a different structure? Journal of Geodynamics 139. https://doi.org/10.1016/j. jog.2020.101766

Kassaras I, Papadimitriou P, Kapetanidis V, Voulgaris N (2017) Seismic site characterization at the western Cephalonia Island in the aftermath of the 2014 earthquake series. Int J Geo-Eng 8:7. https://doi.org/10.1186/s40703-017-0045-z

Kassaras I, Kapetanidis V, Ganas A, Tzanis A, Papadimitriou P, Kouskouna V, Karakonstantis A, Valkaniotis S, Chailas S, Sakkas V, Kosma C, Bozionelos G, Tsironi V, Giannaraki G (2020) The New Seismotectonic Atlas of Greece (v1.0) and 
its implementation. Geosciences 10(11):447. https://doi. org/10.3390/geosciences 10110447

Kempton J, Stewart JP (2006) Prediction equations for significant duration of earthquake ground motions considering site and near-source effects. Earthquake Spectra 22(4):985-1013

Konno K, Ohmachi T (1998) Ground-motion characteristics estimated from spectral ratio between horizontal and vertical components of microtremor. Bull Seismol Soc Am 88(1):228-241

Kontoes C, Elias P, Sykioti O, Briole P, Remy D, Sachpazi M, Veis G, Kotsis I (2000) Displacement field and fault model for the September 7, 1999 Athens earthquake inferred from ERS2 satellite radar interferometry Geophys. Res Lett 27: 3989-3992

Kouskouna V, Malakatas N (2000) Correlation between EMS98 with damage reported of the earthquake of 7 th September 1999. Annales Géologiques des Pays Helléniques, XXXVIII/ B:187-196

Kouskouna V, Ganas A, Kleanthi M, Kassaras I, Sakellariou N, Sakkas G, Manousou E, Tsironi V, Karamitros I, Tavoularis N, Valkaniotis S, Bossu R (2019) The Athens 19/07/2019 $\mathrm{M}_{\mathrm{w}} 5.1$ earthquake - preliminary macroseismic report. https://www.emsc-csem.org/\#2

Kouskouna V, Kaperdas V, Sakellariou N (2020) Comparing calibration coefficients constrained from early to recent macroseismic and instrumental earthquake data in Greece and applied to eighteenth century earthquakes. J Seismol 24:293-317. https://doi.org/10.1007/s10950-019-09874-7

Lekkas E (2001) The Athens earthquake (7 September 1999): intensity distribution and controlling factors. Eng Geol 59: 297-311. https://doi.org/10.1016/S0013-7952(00)00119-8

Lomax A, Virieux J, Volant P, Thierry-Berge C (2000) Probabilistic earthquake location in $3 \mathrm{D}$ and layered models. In: Thurber $\mathrm{CH}$, Rabinowitz N (eds) Advances in seismic event location. Kluwer Academic Publishers, Dordrecht/ Boston/London, pp 101-134. https://doi.org/10.1007/97894-015-9536-0_5

Louvari E, Kiratzi A (2001) Source parameters of the 7 September 1999 Athens (Greece) earthquake based on teleseismic data. J Balkan Geophys Soc 4:51-60

Nakamura Y (1989) A method for dynamic characteristics estimation of subsurface using microtremor on the ground surface. Railway Technical Research Institute, Quarterly Reports 30:25-33

Nakamura Y (2000) Clear identification of fundamental idea of Nakamura's technique and its applications. In: Proceedings of 12th world conference on earthquake engineering, Auckland

Okada Y (1985) Surface deformation due to shear and tensile faults in a half-space. Bull Seismol Soc Am 75:1135-1154

Papadimitriou P, Voulgaris N, Kassaras I, Kaviris G, Delibasis N, Makropoulos K (2002) The $\mathrm{M}_{\mathrm{w}} 6.0,7$ September 1999 Athens earthquake. Nat Hazards 27:15-33. https://doi. org/10.1023/A:1019914915693

Papazachos C, Papaioannou C (1997) The macroseismic field of the Balkan area. J Seismol 1:181-201

Papazachos CB, Karakostas BG, Karakaisis GF, Papaioannou CA (2001) The Athens 1999 mainshock $\left(M_{w} 5.9\right)$ and the evolution of its aftershock sequence. Bull Geol Soc Gr 34:15811586. https://doi.org/10.12681/bgsg. 17266
Pavlides SB, Papadopoulos GA, Ganas A (1999) The 7th September 1999 unexpected earthquake of Athens: preliminary results on the seismotectonic environment. In: 1st conference "advances on natural hazards mitigation - experiences from Europe and Japan", Athens 3-4 November 1999, pp 80-85

Pomonis A (2002) The mount Parnitha (Athens) earthquake of September 7, 1999: a disaster management perspective. Nat Hazards 27:171-199. https://doi.org/10.1023 /A:1019989512220

Rodriguez VHS, Midorikawa S (2002) Applicability of the H/V spectral ratio of microtremors in assessing site effects on seismic motion. Earthq Eng Struct Dyn 31:261-279

Sakellariou N., Pomonis A., Kouskouna V., Kaviris G., Sakkas G., Misailidis I., Tzouxanioti M (2019) Seismic vulnerability categorization of the Greek building stock. 15th International Congress of the Geological Society of Greece, Athens, 22-24 May, Harokopio University of Athens, Greece, Bulletin of the Geological Society of Greece, Sp. Publ. 7, Ext. Abs. GSG2019-087

Sakkas G, Sakellariou N (2018) An algorithm developed in Matlab for the automatic selection of cut-off frequencies, in the correction of strong motion data. Acta Geophys 66:425448. https://doi.org/10.1007/s11600-018-0150-1

Sakkas G, Kouskouna V, Makropoulos K (2010) Seismic hazard analysis in the Ionian Islands using macroseismic intensities. Hell J Geosc 45:239-248

SESAME (2004) Guidelines for the implementation of the H/V spectral ratio technique on ambient vibrations: measurements, processing and interpretation. SESAME Eur. Res. Project, WP12, Del. D23.12, 63pp

Skarlatoudis AA, Papazachos CB, Margaris BN, Theodulidis BN, Papaioannou C, Scordilis KI, E.M., Karakostas V. (2003) Empirical peak ground motion predictive relations for shallow earthquakes in Greece. Bull Seismol Soc Am 93:2591-2603

Tarantola A, Valette B (1982) Generalized nonlinear inverse problems solved using the least squares criterion. Rev Geophys Space Phys 20:219-232. https://doi.org/10.1029/RG020i002 p00219

Tilford NR, Chandra U, Amick DC, Moran R, Snider F (1985) Attenuation of intensities and effect of local site conditions on observed intensities during the Corinth, Greece, earthquakes of 24 and 25 February and 4 March 1981. Bull Seismol Soc Am 75:923-937

Tselentis G-A, Danciu L (2008) Empirical relationships between modified Mercalli intensity and engineering ground-motion parameters in Greece. Bull Seismol Soc Am 98:1863-1875. https://doi.org/10.1785/0120070172

Van Noten K, Lecocq T, Sira C, Hinzen K-G, Camelbeeck T (2017) Path and site effects deduced from merged transfrontier internet macroseismic data of two recent M4 earthquakes in northwest Europe using a grid cell approach. Solid Earth 8:453-477. https://doi.org/10.5194/se-8-453-2017

Wald DJ, Quitoriano V, Dengler LA, Dewey JW (1999a) Utilization of the internet for rapid community intensity maps. Seismol Res Lett 70:680-697

Wald DJ, Quitoriano V, Heaton TH, Kanamori H (1999b) Relationships between peak ground acceleration, peak 
ground velocity, and modified Mercalli intensity in California. Earthquake Spectra 15:557-564

Wald DJ, Quitoriano V, Worden B, Hopper M, Dewey JW (2011) USGS “Did You Feel It?" Internet-based macroseismic intensity maps. Ann Geophys 54/6:688-707. https://doi. org/10.4401/ag-5354

Wells D.L., Coppersmith K.J. (1994). New empirical relationships among magnitude, rupture length, rupture width, rupture area, and surface displacement. Bull Seism. Soc Am 84: 974-1002
Wessel P., Smith W.H.F., Scharroo R., Luis J.F., Wobbe F. (2013). Generic mapping tools: improved version released. Eos, trans. Am. Geophys. Union, 94: 409-410

Zahradnik J (2001) Focal mechanism of the Athens 1999 earthquake by ASPO method, Res. Report, Faculty of Math. and Phys., Charles University

Publisher's note Springer Nature remains neutral with regard to jurisdictional claims in published maps and institutional affiliations. 